\title{
The Relationship between Helicobacter Pylori and Extra-Gastrointestinal Infections
}

\section{Mohammad Darvishi ${ }^{1}$, Majid Noori ${ }^{2}$, Mohammad Reza Nazer ${ }^{3}$, Saeed Soleiman-Meigooni ${ }^{2}$, Mojgan Forootan ${ }^{4 *}$}

1. Infectious Diseases and Tropical Medicine Research Center (IDTMRC), Department of Aerospace and Subaquatic Medicine, AJA University of Medical Sciences, Tehran, Iran

2. Infectious Diseases and Tropical Medicine Research Center (IDTMRC), Department of Infectious Disease, School of Medicine, AJA University of Medical Sciences, Tehran, Iran

3. Department of Infectious Diseases, Hepatitis Research Center, Lorestan University of Medical Sciences, Khorramabad, Iran

4. Department of Gastroenterology, Gastrointestinal and liver Diseases Research Center (RCGLD), Shahid Beheshti University of Medical Sciences, Tehran, Iran

\section{ABSTRACT}

Helicobacter pylori (H. pylori) has been identified as the major agent in human gastric cancer by the International Agency for Research on Cancer (IARC). Infection caused by H. pylori plays a leading role in many disorders including duodenal and gastric ulcer, chronic gastritis, lymphoid tissue lymphoma, and gastric adenocarcinoma. In addition, growing evidence suggests that $H$. pylori interferes with many biological processes, causing or affecting the incidence of several extra-gastrointestinal disorders. The bacteria are known to cause iron deficiency anemia (IDA), vitamin B12 deficiency, and immune thrombocytopenic purpura (ITP). Latest studies suggest that H. pylori may contribute in many disorders such as insulin resistance, acute coronary syndrome, neurological diseases among others, which previously was attributed to other factors and conditions. There are several mechanisms proposed for $\mathrm{H}$. pylori inducing low-grade chronic inflammation and the incidence of molecular imitation mechanisms. This present study discusses the most critical diseases related with the role of H. pylori and related infection (especially extra-gastrointestinal diseases) in these diseases.

Keywords: Helicobacter pylori, Gastrointestinal diseases, Extragastric diseases, Pathogenic factors

Received: 2020/02/11; $\quad$ Accepted: 2020/09/09; Published Online: 2020/09/26

\begin{tabular}{|c|c|}
\hline Corresponding Information: & $\begin{array}{l}\text { Mojgan Forootan, Department of Gastroenterology, Gastrointestinal and liver Diseases Research Center (RCGLD), Shahid } \\
\text { Beheshti University of Medical Sciences, Tehran, Iran Email: drmojganforootan@gmail.com }\end{array}$ \\
\hline (c) (i) (5) & $\begin{array}{l}\text { Copyright (C) 2020, This is an original open-access article distributed under the terms of the Creative Commons Attribution-noncommercial } 4.0 \text { International License which } \\
\text { permits copy and redistribution of the material just in noncommercial usages with proper citation. }\end{array}$ \\
\hline
\end{tabular}

Use your device to scan and read the article online

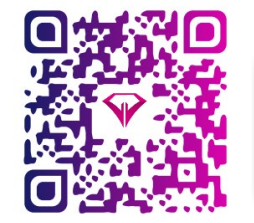

Darvishi M, Nouri M, Nazer M.R, Soleiman-Meigooni S, Forootan M. The Relationship between Helicobacter Pyloriand Extra-Gastrointestinal Infections. Iran J Med Microbiol. 2020; 14 (6):524-565

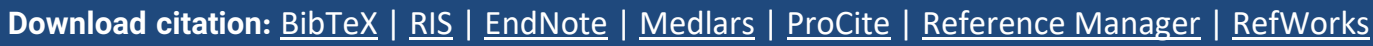
Send citation to:
8 Mendeley
(2) Zotero
Hi RefWorks

\section{Introduction}

Helicobacter pylori (H. pylori) first discovered by two Australian physicians Robin warren and Barry Marshall in 1982. H. pylori, a helical gram-negative bacterium, is known as a significant pathogen causing infection in people, affecting about 4.4 billion people in the world (about $50-60 \%$ of the world's population in 2015) (1 -
5). Although the main host for H. pylori is stomach, it may reach the distal esophagus or proximal duodenum if gastric metaplasia is presented (6). Unlike many bacteria, $H$. pylori is highly compatible to live in the stomach. Many factors including acidity, peristalsis, nutrient availability, innate and acquired 
host immunity, and competition between microbes limit the presence of bacteria in the human stomach. The special characteristics of $H$. pylori enables it to reduce the acidity of the environment it lives in $[7,8]$. Many gastrointestinal diseases including gastritis, dyspepsia, peptic and duodenal ulcer, gastric adenocarcinoma, and gastric mucosa-associated lymphoid tissue (MALT) lymphoma are strongly correlated with $H$. pylori infection $(5,9)$. $H$. pylori has been classified into the first group of carcinogens (meaning causing cancer) of human gastric cancer by IARC in 1994. Chronic infection by $\mathrm{H}$. pylori in stomach tissue contribute leads to chronic inflammation or a cancer-prone environment that eventually cause gastric cancer (1). The prevalence of infections caused by this pathogen varies in different countries, for example, in Latin America (75-83\%), Japan (39.6), and the United States (17.1) (9). There is a direct correlation between $H$. pylori infection and its transmission with poor socioeconomic status e.g. poor health, water pollution, low quality lifestyle, poor diet, smoking, and lack of physical activity (1).

The association between $H$. pylori and extragastrointestinal disorders have also been reported in several studies. The first category of these disorders are unusual metabolic profiles, e.g. diabetes, insulin resistance, hypertension, dyslipidemia, and obesity, all of which are part of metabolic syndrome. As a result, unusual profiles lead to increased risk of cardiovascular disease due to atherosclerosis and vascular disorders. The $2^{\text {th }}$ category of disorders is related to the immune system response, involving atopic diseases, asthma, hives, and autoimmune thyroid diseases (ATDs). The third category of these diseases includes immune thrombocytopenic purpura (ITP), migraine, iron deficiency anemia (IDA), deficiency of vitamin B12, glaucoma, and severe nausea and vomiting [10]. The proposed mechanism for these diseases is that chronic Infection by $\mathrm{H}$. pylori causes chronic inflammation caused by the complex response of biological tissue. Inflammatory factors like tumor necrosis factor (TNF) and cytokines interleukin (IL) are specifically due to the chronic-low-grade inflammation, which is common in infectious inflammation pathways in gastritis, diabetes, metabolic syndrome, atherosclerosis, and obesity. The inflammatory factors caused by the mucosa of enflamed stomach are continuously discharged to the bloodstream, thereby affecting the metabolic profile. As a result of cytokine induced by $H$. pylori, low-grade chronic inflammation caused the infection of $H$. pylori my lead to extra-gastrointestinal disorders $(1,10,11)$. Recent studies indicate the importance of study on gastrointestinal and extra-gastrointestinal diseases associated with $H$. pylori infections. In this review study, our research team will introduce the most important $H$. pylori-related disorders (especially extra- gastrointestinal diseases) and discuss the role of $H$. pylori in extra-gastrointestinal disorders.

\section{Materials and Methods}

The present study aimed to assess the relationship of H. pylori with extra-gastrointestinal infections by classifying the subjects researched from 1980 to 2019. This evaluation was conducted in 2020 and databases including PubMed, Medline, Cochran Library, WHO, and Iranmedex were used to obtain the desired articles. Aiming to collect data on the relationship of $H$. pylori with extra-gastrointestinal infections, the keywords such as "gastrointestinal diseases", "Helicobacter pylori", "extragastrointestinal diseases", and "pathogenic factors" were used. Finally, out of 210 retrieved papers, 51 papers were identified as appropriate and examined in terms of subject, content structure, and relevance.

\section{An Overview of $\boldsymbol{H}$. Pylori Infection and Pathogenic} Factors

After entering to the stomach of its host, $H$. pylori uses urease activity to neutralize the acidic conditions of the stomach (6). The bacterium may express inflammatory pathogens associated with inflammation and inflammatory symptoms in infected patients. The main pathogens of $H$. pylori include gamma-glutamyl transpeptidase (GGT), vacuolating cytotoxin A (VacA), and a product of the cytotoxin-associated gene $A$ (CagA), which cause damage to host tissues. The products of these factors are secreted by $H$. pylori into host cells [12]. Studies have shown that CagA may have a leading role in the production of IL- 8 and the activation of nuclear factor kappa-B (NF- $\kappa \beta)$. In addition, CagA expression induces IL-8 production and NF- $\beta$ transport in gastric epithelial cells. VacA of $H$. pylori is able to induce intracellular vacuolization in gastric epithelial cells. It is therefore assumed to contribute to damage to the stomach and duodenal mucosa that eventually lead to ulcer. Therefore, pathogenic factors VacA and CagA play a critical role in H. pylori pathogenicity and infection [9]. Other factors, including Bab2 adhesion factor, outer inflammatory protein A (OipA), the induced by contact with epithelium antigen (iceA) factor, sialic acid-binding Adhesin (SabA), and duodenal ulcer promoting gene $A$ (dupA) are involved in mucosal colonization. In addition, these factors secrete cytokines to initiate innate immunity and activate neutrophils in the pathogenesis of the gastric epithelial layer, which forms the main link $H$. pylori with the host, leading clinical diseases such as gastritis and ulcers. In short, four steps are required in establishment and pathogenicity of $H$. pylori as follows:

1. Surviving the acidic conditions of stomach

2. Movement to epithelial cells via nodules 
3. Connection to host receptors via adhesion factors

Damaging tissues via pathogenic factors (Figure 1) $(9,12,13)$.

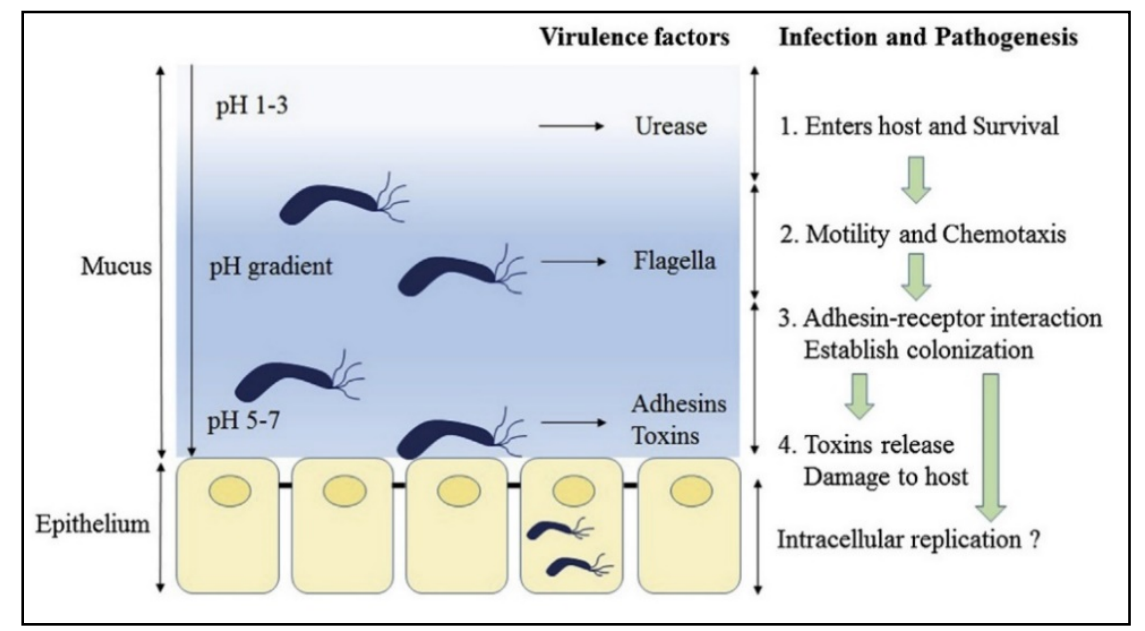

Figure 1. Schematic diagram of pathogenesis and infection of H. pylori. (9)

\section{Epidemiology and Natural History}

A steady decrease has been noticed in the prevalence of $H$. pylori infection and gastric cancer among most populations, especially in affluent Western societies in recent decades. Dominant bacterial genotypes also vary in different societies. Communities with higher risk of gastric cancer have higher pathogenicity strains (14). In some populations, more than one strain with different pathogenicity is located in the gastric mucosa. In these societies, along with the reduction of cancer rates and the spread of infection, great changes have taken place, including economic development; the most important changes include improving the health status of homes, reducing family population, changing eating habits (e.g., consuming less salt and more fresh vegetables and fruits), improving cooling equipment, and controlling infectious diseases. Excessive consumption of antibiotics to deal other infectious disorders may have adverse effects on the prevalence of $\mathrm{H}$. pylori infection $(12,15)$.

Clinically, $H$. pylori infection has variable course and is affected by the host and microbial agents. The gastritis distribution and pattern is highly correlated with the risk of several clinical disorders including as mucosal atrophy, duodenal and gastric ulcers, gastric lymphoma, and gastric cancer (16). Antral-predominant gastritis is the most prevalent type of $H$. pylori gastritis and patients with this type of gastritis are more prone to duodenal ulcers. However, patients with multifocal atrophic and corpus predominant gastritis are at higher risk to develop ulcers, intestinal metaplasia, gastric atrophy, and eventually gastric cancer. Gastric adenocarcinoma caused by $H$. pylori infection starts with gastritis and results in atrophy followed by intestinal dysplasia, metaplasia, and gastric cancer, respectively. $H$. pylori contributes to most types of gastric and duodenal ulcers. The prevalence of gastric ulcer in a person affected by $\mathrm{H}$. pylori infection varies from $3 \%$ in the USA to $25 \%$ in Japan. Gastric cancer is considered as the $2^{\text {th }}$ leading reason of death from cancer. The relation of $\mathrm{H}$. pylori with the increased risk of gastric cancer is confirmed in various research, so that in 1994 it was definitively classified as type 1 carcinogen $(8,12,15,17)$. 


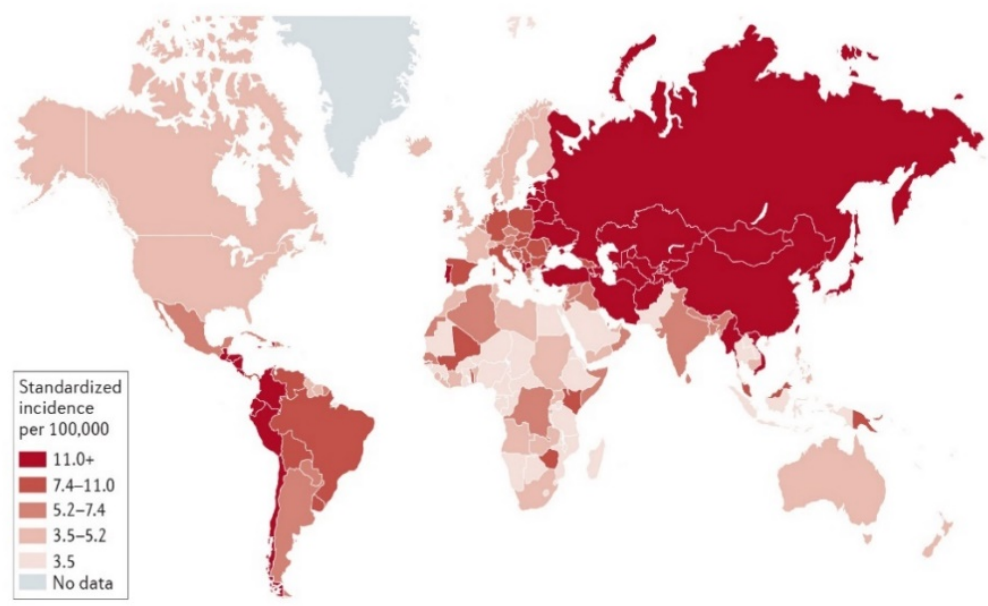

Figure 2. Outbreak of gastric cancer in 2012 (15)

Studies have shown that almost all patients with MALT lymphoma are effected by $H$. pylori infection, i.e. H. pylori infection significantly elevate the risk of developing MALT lymphoma. Patients who are in the primary stages of the disease are more likely to recover completely with antibiotic treatment, but people with progressed stages of the disease (wounds, submucosal lesion, wall attack, or lymphadenopathy) are more likely in need of lymphoma treatment. Patients with intestinal metaplasia should be tested for $\mathrm{H}$. pylori infection, as intestinal metaplasia is an autonomous risk factor of gastric malignancy. After eradication of the bacterium, the probability of gastric lymphoma (MALT) recurrence is about $70-80 \%(5,8,12,15)$.

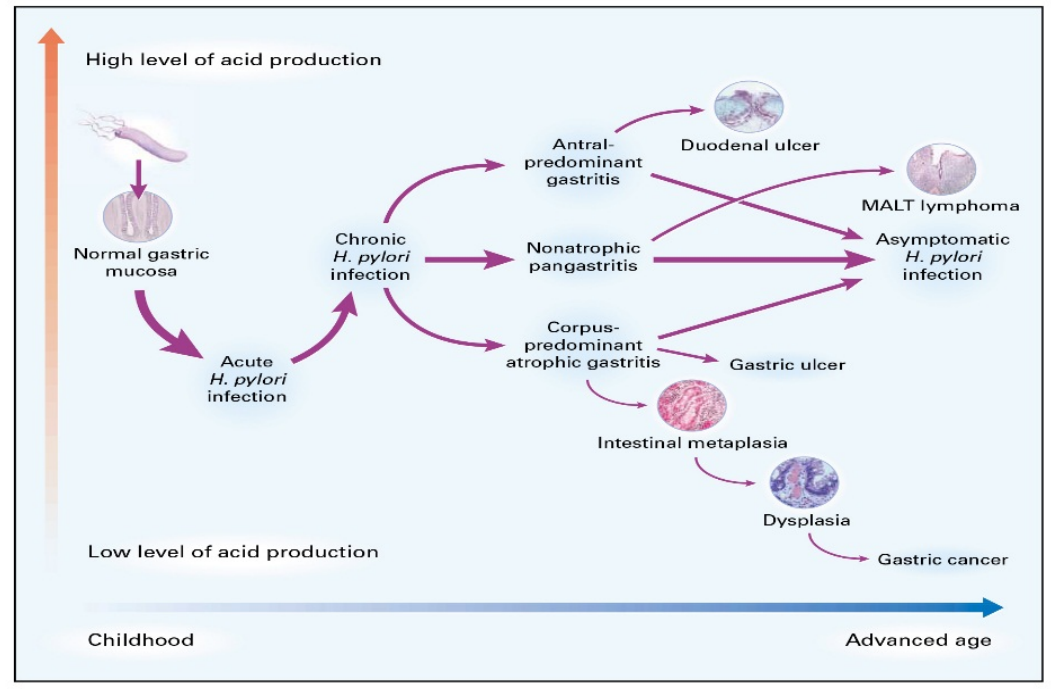

Figure 3. The natural course of $H$. pylori infection (17).

It is estimated that about $5 \%$ of people with dyspepsia (most of them functional) were due to $H$. pylori infections. Patients with $H$. pylori may have symptoms of dyspepsia without the presence of macroscopic lesions in the gastroduodenal mucosa. This is known as dyspepsia and various pathogenic mechanisms are involved in it. The results of various experiments and data from several extensive studies have noted that eradicating $H$. pylori to improve dyspepsia symptoms is more cost-effective statistically, and has a better effect on the natural history of functional dysplasia compared with placebo. The reasons for the recurrence of dyspeptic symptoms in some patients following elimination of $H$. pylori have not been fully elucidated yet $(12,15,18)$.

Gastroesophageal reflux disease (GERD) is referred to a multifactorial disorder which causes the gastric acid to reflux into the esophagus, resulting tissue injury and certain symptoms such as burning and vomiting. Increased prevalence of GERD symptoms indicates decreased prevalence of peptic ulcer and $H$. pylori. The exact link among $H$. pylori infection and GERD seems complex. However, current evidence does not support a definitive conclusion as to whether patients infected by $H$. pylori have the same GRED symptoms as non-infected patients 
$(19,20)$. Studies to date have noted that the treating infection caused by $H$. pylori leads to worsening of GERD. According to a theory that suggests an exact link between $H$. pylori infection and GERD, because the induction of gastric atrophy by bacteria and the resulting lack of stomach acid, the development of GERD in individuals is reduced, which is a potential risk for Barrett's esophagus and esophageal adenocarcinoma. Therefore, the concern is that eradication may cause the spread of GERD symptoms and lead to the spread of esophageal adenocarcinoma worldwide $(15,21)$.

In recent years, many scientists around the world have studied the association between extra-gastrointestinal diseases and $H$. pylori infection. In fact, $H$. pylori possibly is associated with a variety of biological procedures both outside and inside the gastrointestinal tract and is likely to determine and affect the incidence of many extragastrointestinal disorders. However, the association of $H$. pylori with sideropenic anemia and idiopathic thrombocytopenic purpura has already been identified. Recent evidence shown that $H$. pylori is related with increased risk of acute coronary syndrome, insulin resistance, neurogenic and respiratory diseases, and other disorders. Various pathogenic mechanisms such as the induce of low-grade chronic inflammation and the incidence of molecular mimicry mechanisms have been proposed in this field $(\mathbf{1 1}, \mathbf{2 2})$.

\section{Extragastric Diseases}

\section{Cardiovascular Diseases}

Wang et al. (2018) studied the relationship between the infection by $H$. pylori and the risk of coronary heart disease (CHD). They designed a comprehensive cohort study using Taiwan's National Health Database and compared 3,713 patients with peptic ulcer disorder treated by anti $H$. pylori medicine with available data of untreated patients. The results of this study showed that mortality was reduced in patients affected by $H$. pylori infection who underwent eradication therapy (23). In their cohort study, Lai et al. (2015) found a direct relationship between $H$. pylori infection and increased prevalence of acute coronary syndrome, even following the elimination of pathogens, and it increases with aging (24). The results of the study conducted by Hughes (2014) on a military group born in the 1930s showed a decrease in the simultaneous heart attack and duodenal ulcers. Hughes concluded that duodenal ulcer is highly associated with the infection with $H$. pylori and one of the reasons for the reduction in heart attacks is the eradication of $H$. pylori (25). Since inflammation has a major role in atherosclerotic plaque rupture, high levels of serum IL- 6 appear to be significantly related to $H$. pylori infection and may actively contribute in ischemic heart disease. Other studies have reported a high level of B-type natriuretic peptide and IL-6 (biomarkers of heart failure) in the body of patients suffering from coronary artery disorder infected with CagA-positive strains (11).

\section{Diabetes and Insulin Resistance}

Insulin resistance (IR) is among the main pathogens of type 2 diabetes (1). The relationship among $H$. pylori and diabetes was first studied in 1989, and it was found that the rate of infected cases with $H$. pylori was higher in diabetic patients compared the control ( $62 \%$ vs. $21 \%$ ). A systematic review (2011) reported a very significant score in the hemostatic model for assessing insulin resistance in individuals infected with $\mathrm{H}$. pylori in comparison with noninfected individuals in seven cross-sectional analyses (26). Yang et al. (2014) study also showed a meaningful correlation among diabetics and $H$. pylori infection by studying 1,285 subjects (age range: $19-85$ years), and in line with these researchers, similar results were reported by Indian researchers (27). Diabetic patients infected with H. pylori have poorer glycemic control than non-infected cases. In addition, other researchers identified higher diabetes rates of prevalence in $H$. pylori infected patients and there is a positive relationship between IR and $H$. pylori infection $(\mathbf{1 1}, \mathbf{2 8})$. The potential mechanism proposed is that $H$. pylori lipopolysaccharides activate Tolllike receptors, which are often expressed in macrophages and dendritic cells, causing energy absorbing, fat accumulating and eventually IR. In severe inflammation, cytokines inhibit the insulin to affect its receptor via phosphorylation of residual serine in the receptor, leading to IR (1).

Despite the significant correlation between diabetes and $H$. pylori infection, the issue is still under debate among researchers. The reason for this disagreement is different results in comparing the levels of diabetes pre and after the $H$. pylori eradication in several experiments. Most of the experiments have reported the favorable effects of $H$. pylori eradication in reducing diabetes, but other reports indicate a lack of correlation between IR level and diabetes before and after the eradication (1, 11, 29). Numerous studies have shown that diabetics are more susceptible to infection. Diabetes-induced humoral and cellular immune disorders may increase a person's susceptibility to $H$. pylori infection. On the other side, diabetes reduces the rate of acid secretion and gastrointestinal motility, which may contribute to $H$. pylori colonization and gastrointestinal infection. Alterations in glucose metabolism may also lead to chemical changes in gastric mucus, which in turn promotes $H$. pylori colonization. In addition, people with diabetes are more exposed to pathogens in the hospital environment than other individuals (30).

\section{Metabolic Syndrome (MetS)}

MetS refers to a set of metabolic disorders which are considered as a risk factor for various gastrointestinal 
diseases as well as cardiovascular diseases. MetS, known as syndrome $\mathrm{x}$ and IR syndrome, has been steadily increasing worldwide and has placed a significant burden on public health (31-33). MetS is so closely related to IR that it is known as one of the mechanisms of MetS expression. $H$. pylori is also regarded as a mechanism involved in the development of MetS. There are multitude studies indicating the global spread of MetS and $\mathrm{H}$. pylori infection, and growing evidence exists regarding the possible link of $\mathrm{H}$. pylori infection with both IR and MetS. Evidence suggests that these syndromes are associated with diseases like cardiovascular disease, diabetes mellitus type 2, abdominal obesity, dyslipidemia, hypertension, and non-alcoholic fatty liver disease (NAFLD).

Nabiour et al. (2006) was the first study that assessed the correlation between $H$. pylori infection and MetS and reported that $H$. pylori infected cases was 1.5 times more prone to MetS compared to healthy individuals (34). Using histological diagnosis of $H$. pylori and urea breath test, Chen et al. (2015) concluded that MetS prevalence in patients with $H$. pylori infection was higher compared to non-infected cases in both males and females (35). A same association between IR and $H$. pylori has also been noted in a systematic review by Polyzos et al. (2011) (36). The relationship of $\mathrm{H}$. pylori eradication with MetS recurrence was investigated to assess the impact of $H$. pylori infection on MetS pathogenicity among black populations. The results of this study showed improvement in three components including plasma glucose, HDL-cholesterol, and systolic and diastolic blood pressure compared to base values following 3 weeks of $H$. pylory eradication (1).

A review article titled "The Possible Role of Helicobacter pylori Infection in Non-alcoholic Fatty Liver Disease" by Cheng et al. (2017) is a good illustration of the mechanism by which $H$. pylori infection affect the development of NAFLD disease. IR is considered as an important part of the development of NAFLD disease and many studies have confirmed the important role of $H$. pylori infection on IR development. Infection by $H$. pylori can increase lowgrade chronic inflammation and levels of antiinflammatory factors, including TNF- $\alpha$ and IL-6, and subsequently activate IKK/NF-KB, causing IR. Inhibiting leptin release by white adipose tissue is another possible effect of $H$. pylori infection, which causes an increase in the activity of desaturase CoA stearoyl (SCDI) in the liver, thereby accelerating the deposition of fat and VLDL-C in the liver tissues (Figure 4). Regarding the interaction between intestines and stomach, $H$. pylori infection may cause other gastrointestinal diseases [37]. Chen et al. (2019) also stated that people infected with $H$. pylori are more susceptible to NAFLD than those not infected by $H$. pylori (38).

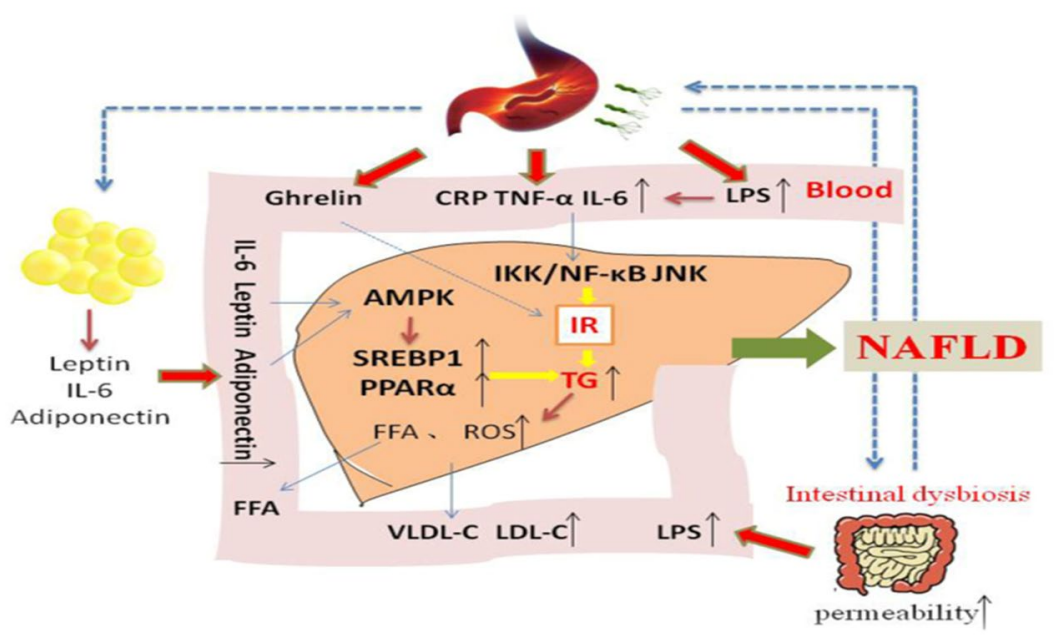

Figure 4. Possible relationship between NAFLD and H. pylori infection (38).

\section{Neurogenic Diseases}

The relationship between neurodegenerative diseases and neuroinflammation can potentially be triggered by environmental conditions and disruption of the bloodbrain barrier. Recent studies outlined that various pathogens (including $H$. pylori) may reach the central nervous system (CNS) via blood flow, gastrointestinal tract, and olfactory tract. Thus, $H$. pylori is able to induce cellular and humoral immune responses and also, interact with CNS components through sharing homologous epitopes, thereby causing damage to nerve tissue. Hence, one could associate $H$. pylori with several CNS-related degenerative and autoimmune diseases (39-42). 


\section{Proposed entrance of $\mathrm{Hp}$ in $\mathrm{CNS}$}

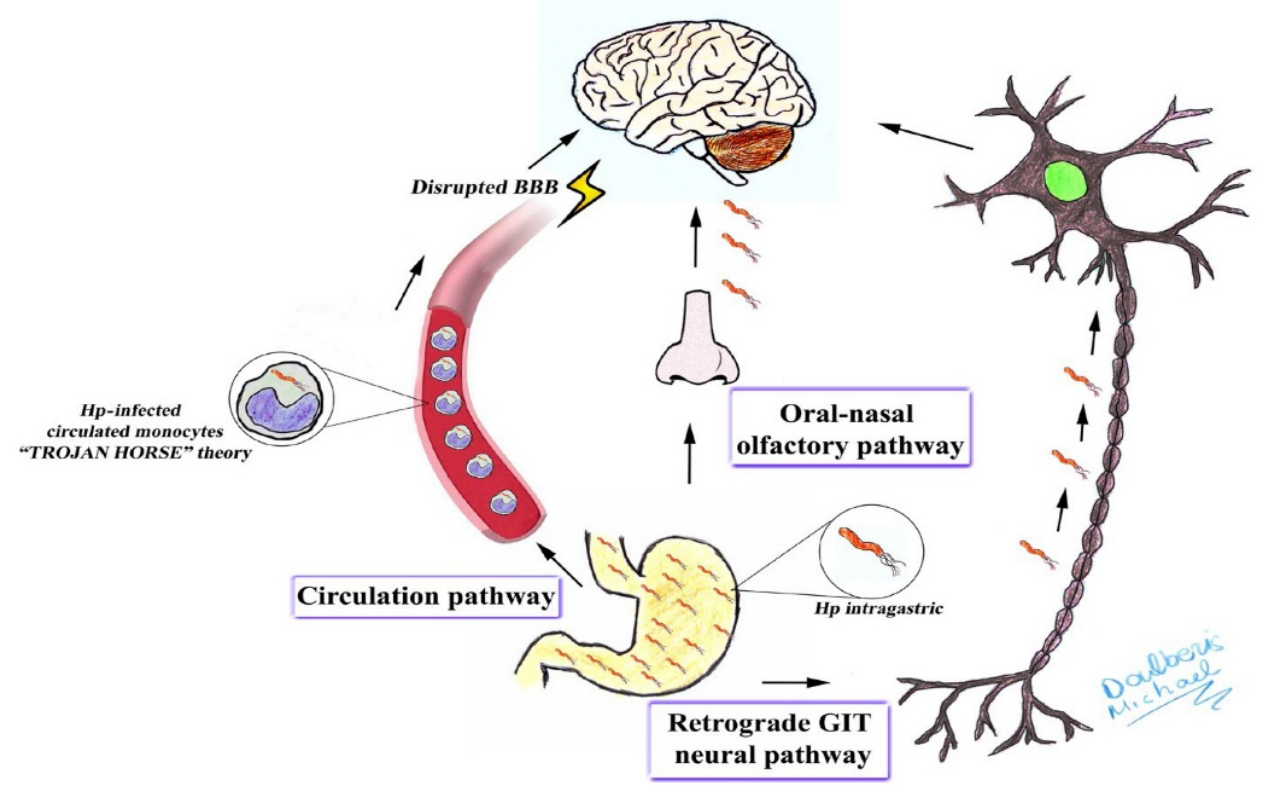

Figure 5. Schematic representation of three theories that mechanically explain the possibility of $H$. pylori entering the CNS (40)

\section{Parkinson's Disease}

Parkinson's disease (PD) ranked in the $2^{\text {th }}$ place among neurological disorder worldwide. The disease has been specified as accumulating cytoplasmic proteins, including $\alpha$-synuclein, causing gradual degeneration of dopaminergic neurons (43). Degeneration leads to tremors, stiffness, and difficulty with movement as symptoms of PD. The risk of PD may increase in the presence of $H$. pylori infection. L-3, 4-Dihydroxyphenyl alanine (L-dopa), a dopamine precursor, is prescribed to treat PD. The accessibility of L-DOPA may be affected by $H$. pylori infection via disrupting the duodenal mucosa in which initial L-DOPA uptake occurs. Recent studies have argued that $H$. pylori eradication improves L-DOPA accessibility and reduces motor instabilities in PD patients. Parkinsonism is also a neurological disease with same symptoms as PD. If anti-inflammatory cytokines such as IL$1 \beta$, TNF- $\alpha$, and IL- 8 are presented in the bloodstream, the immune response induces a blood-brain barrier disorder and ultimately causes neurotoxicity and neuroinflammation. Researchers have found that infection by $H$. pylori provides the necessary basis for autoimmune disease, which in turn leads to nerve damage and eventually Parkinsonism $(41,44,45)$.

\section{Alzheimer's Disease (AD)}

Alzheimer's disease (AD) is regarded as the most prevalent form of dementia, especially in industrialized countries, affecting approximately 20 million people worldwide [40]. AD is a progressive neurogenic disorder specified by nerve death and synaptic loss due to intra- and extra-cellular accumulation of neurofibrillary tangles and beta-amyloid deposits in those brain areas that are involved in cognitive and memory processes The inflammatory reaction has an significant role in the pathophysiology of AD. Given the $H$. pylori-induced inflammatory reactions and high levels of $H$. pylori, TNF- $\alpha$, $\mathrm{IL}-8$, and IgG in the cerebrospinal fluid (CSF) of $\mathrm{H}$. pyloriinfected patients suffering $A D$, it could be concluded that H. pylori may contribute in AD. This confirms the results of the studies that noticed an improvement in cognitive status, functional parameters, and survival of $A D$ patients after $H$. pylori eradication (41). Chronic atrophic gastritis caused by $\mathrm{H}$. pylori reduces the concentration of $\mathrm{B}$ vitamins in the serum and thus increases the concentration of homocysteine; concentration of homocysteine in serum corresponds with the intensity of dementia. Oxidative damage may be induced by homocysteine in the brains of patients with mild cognitive disorder is possible. The information suggests that oxidative damage may be considered as one of the first events occurs at the onset and development of $A D(41,44)$.

\section{Multiple Sclerosis}

Multiple sclerosis (MS) is a complex multifactorial and autoimmune disease, which causes demyelinating inflamed lesions in the CNS system. The etiology of MS is not yet fully understood. Several environmental factors, including microbial agents, are known to cause the disease. Among microbial agents, $H$. pylori has been considered as a microbial agent of the disease. This hypothesis is confirmed by the high prevalence and occurrence of gastrointestinal symptoms in MS (44, 46, 47). H. pylori infections are known as important risk factors in the progression of anti-aquaporin 4 (AQP4) and the results of some studies confirm the improvement of 
patients after $H$. pylori eradication. Neuromyelitis optica (NMO) is an inflammatory disorder that electively influences the spinal cord and optic nerve. Optic neuromyelitis development may be affected by chronic infection via molecular mimicry existed between bacterial AQP4 and human AQP4. Moreover, the protein responsible for activating $H$. pylori neutrophil is involved in pathogenesis by inducing activation and migration of neutrophils $(42,44)$.

\section{Ischemic Stroke}

Studies indicate that some infectious agents have a role in the progression of neurological disorders like ischemic stroke. There are a positive relationship between $\mathrm{H}$. pylori infection and the occurrence of stroke. The pathophysiological mechanism of most strokes is cerebrovascular and carotid occlusion [48]. The presence of CagA-positive strains and $\mathrm{H}$. pylori-chronic infection are two main risk factors for stroke. Likewise, there are a clear relationship between CagA-positive strains of $H$. pylori and higher risk of atherosclerotic strokes in patients with active infection. The underlying mechanism through which chronic $H$. pylori infection augments the risk of ischemic stroke is not yet wholly known. H. pylori is thought to affect coagulation by activating platelets. According to the results of various studies, the levels of plasma and LDL cholesterols, IL-8, and fibrinogen were significantly decreased following six months of $H$. pylori infection eradication compared to the control group and patients infected with $H$. pylori suffering from stroke $(44,48,49)$.

\section{Hematological Diseases}

\section{Iron Deficiency Anemia (IDA)}

There are a large body of studies examining the relation between IDA and H. pylori infection. Blaser et al. (1991) described the relationship between hemorrhagic gastric and infection by $H$. pylori, and also suggested a possible association between IDA and $H$. pylori infection $(7,51)$. The same association has been confirmed in children and adults in several studies [50-53]; however, few studies did not confirm this association. A meta-analysis consisting 15 case-control studies was conducted by Qu et al. (2010) in order to examine the association between IDA and $\mathrm{H}$. pylori infection. In 5 studies, the diagnosis of the infection was successfully done using endoscopy and histological tests, which did not include gastric ulcer and gastric cancer cases. In 10 other studies, $H$. pylori infection was identified using serological tests and urea breath test; the data showed with high reliability the association between $H$. pylori infection and higher risk of IDA in these people (54). A recent study also confirmed the relationship between IDA and $H$. pylori infection (55). Improvement of IDA patients following $H$. pylori eradication in the absent of iron supplementation has also been confirmed in other studies (51).
H. pylori can result in IDA through certain mechanisms. First, iron loss may increase because of peptic ulcer disorder, hemorrhagic gastritis, and gastric adenocarcinoma. Secondly, the role of $\mathrm{H}$. pylori CagA protein has been confirmed in the absorption of iron from interstitial holotransferrin. The rate of iron uptake by $\mathrm{H}$. pylori increases during bacterial development. In summary, the relationship between IDA and $H$. pylori has been established in various research, and currently national and international instructions suggest $H$. pylori infection eradication in IDA patients $(\mathbf{5 1}, \mathbf{5 2})$.

\section{Immune Thrombocytopenic Purpura (ITP)}

ITP, formerly known as autoimmune- and idiopathic-thrombocytopenic purpura, refers to an autoimmune disruption specified by isolated thrombocytopenia when other causes are absent. In 1999, the first relation of ITP with $H$. pylori infection was explained in Spain. In addition to this association, several researchers have also reported a significant increase in the number of platelets due to $\mathrm{H}$. pylori eradication from $32 \%$ to $100 \%$ in Italy and $26 \%$ to $100 \%$ in other parts of the world $(50,56)$.

H. pylori affects ITP through several mechanisms. An interesting hypothesis about molecular mimicry outlines that antibodies with cross-reactivity can react with platelet surface antigens as well as $H$. pylori. By washing the platelets of $H$. pylori-infected ITP patients, the researchers identified the CagA protein in the immunoblots, whereas it was not detected in $H$. pylori-infected patients who were free from ITP. Other researchers have outlined that the reaction of $H$. pylori urease with GP IIb/IIla expressed on platelet surface resulted in monoclonal antibodies. Although these results represent a molecular mimicry between platelet surface antigens and $H$. pylori components, the pathogenic role of these cross-reactive antibodies is still unclear [57 Other possible mechanisms may be due to the destabilizing impact of $H$. pylori infection on the balance of Fcy receptor of monocytes/macrophages, resulting the formation of autoantibodies. Based on a recent study, the expression of Fc $\mathrm{R}$ II B in circulating monocytes was reduced in patients infected by $H$. pylori who had IPT. Thus, $H$. pylori may change the balance of Fcy receptor of monocytes/macrophages by reductive regulation (51).

\section{Vitamin B12 Deficiency}

There are several major enzymatic reactions inside the body, in which vitamin B12 acts as the coenzyme, thereby results in DNA synthesis. Lahner et al. (2012) performed a systematic review of 17 studies including a total of 2,454 patients and found a direct association between $H$. pylori infection and low levels of serum vitamin B12 
Homocysteine is an important ingredient of the vitamin B12 metabolism pathway, and many researchers have reported a positive association between $H$. pylori infection and both high serum homocysteine levels and low serum vitamin B12 levels. Reduced homocysteine and increased vitamin B12 serum levels after $H$. pylori eradication have also been reported $(50,58,59)$.

As described in the previous sections, $H$. pylori infection is strongly related with chronic gastritis and disrupts gastric acid and pepsin secretion. Thus, H. pylori is associated with incomplete absorption of vitamin B12 in food, however, the underlying pathophysiological metabolism is still unknown. Pangastritis related with $H$. pylori infection leads to the destruction of gastric parietal cells, which in turn reduces the level of endogenous factors and leads to a decrease in the absorption of vitamin B12 [50,60]. The possible mechanisms that lead to the association between IDA, ITP, and vitamin B12 shortage with $H$. pylori infection are summarized in Figure 6.

\section{Conclusion}

The results of various studies over the years indicate the involvement and impact of $H$. pylori infection on many biological processes associated with gastrointestinal and extra-gastrointestinal diseases. $H$. pylori contribute in several gastrointestinal disorders including peptic and duodenal ulcer, gastritis dyspepsia, gastric adenocarcinoma, and MALT lymphoma. The pathogenic mechanism of these diseases is not fully known yet. The bacterium also causes many extragastrointestinal diseases, including cardiovascular disease, diabetes, IR, MetS, PD, AD, MS, ischemic stroke, IDA, ITP, and deficiency of vitamin B12. The likely mechanism of $H$. pylori leading to these diseases has also been investigated in the last few years. 


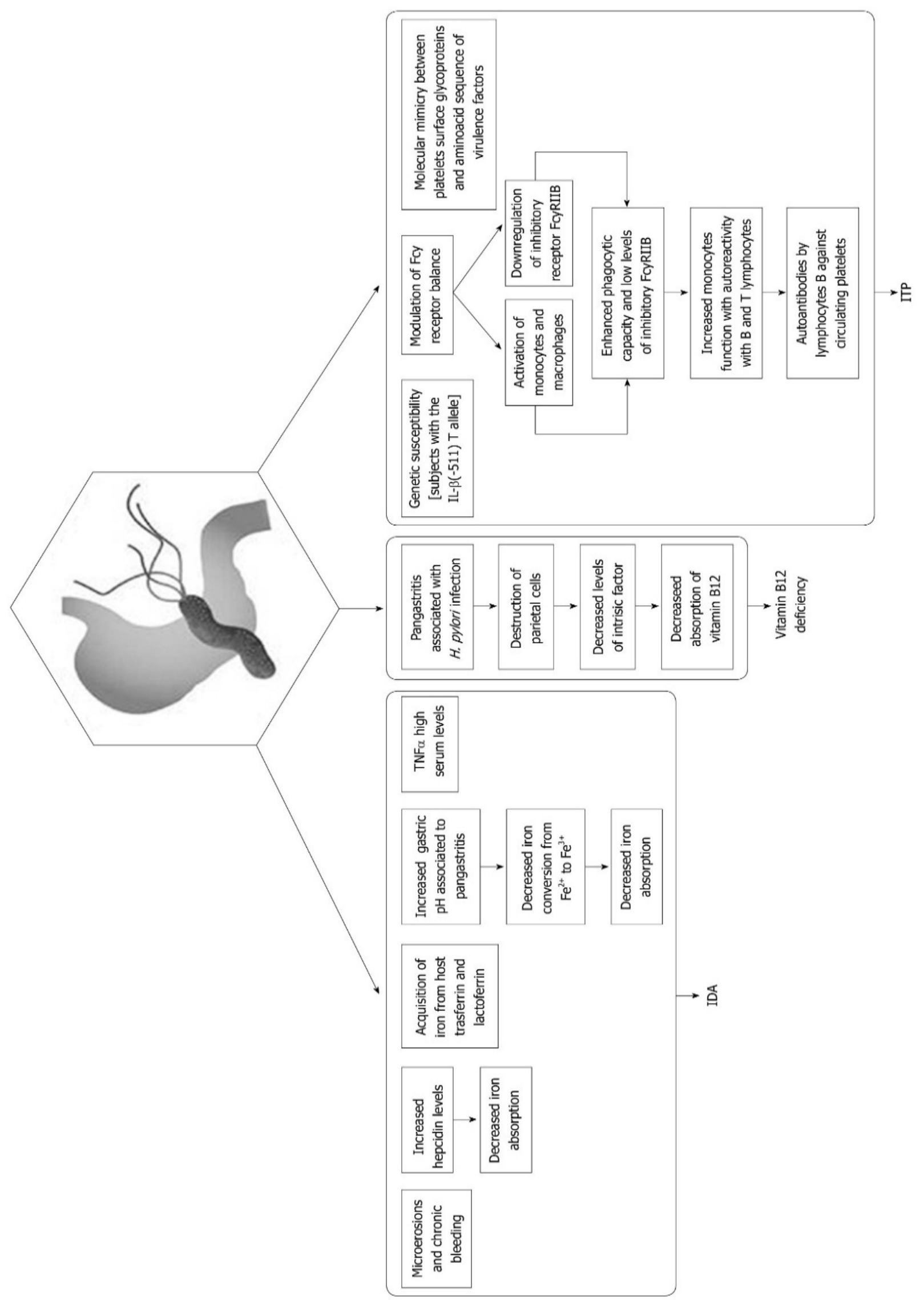

Figure 6. Possible mechanisms leading to the connection between hematologic diseases and the infection by $H$. pylori (50). 


\section{Acknowledgment}

The authors of this study appreciate the assistance of all people who helped us in preparing and composing the paper.

\section{Ethical considerations}

Ethical issues (Including plagiarism, informed consent, misconduct, data fabrication and/or falsification, double publication and/or submission, redundancy, etc.) have been completely observed by the authors.

\section{Funding and support}

This research resulted from an independent research without receiving any financial support.

\section{Conflict of Interest}

Authors declared no conflict of interests. 


$$
\begin{aligned}
& \text { مجله ميكروبشناسى يزشكى ايران }
\end{aligned}
$$

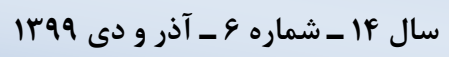

\section{ارتباط مليكوياكتر بيلورى با عفونتهاى خارج از دستكاه كوارش \\ محمد درويشى'، مجيد نورى'، محمد رضا ناظر '، سعيد سليمان ميكونى'، مزَّان فروتن"}

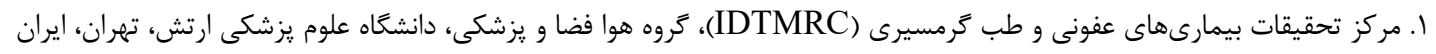

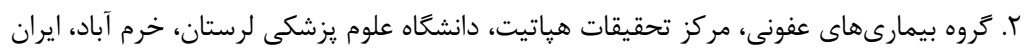

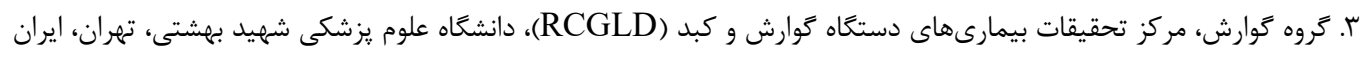

\section{جكيله}

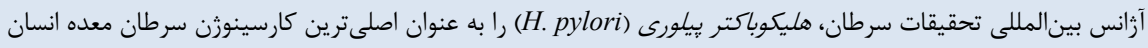

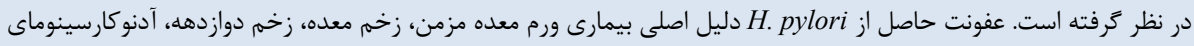

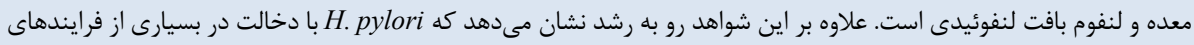

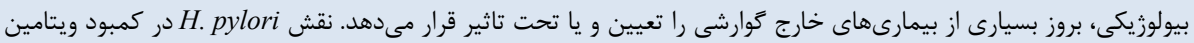

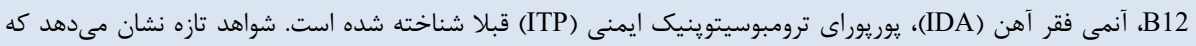
H. pylori

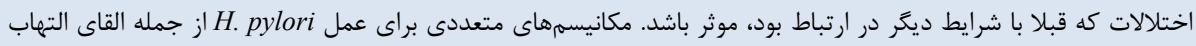

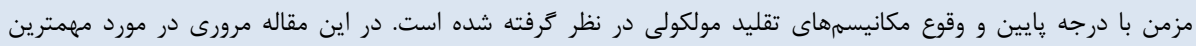

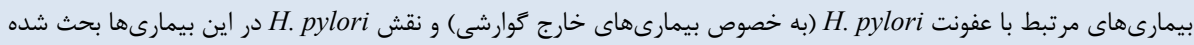

$$
\text { كليد وازهها: هليكوباكتر ييلورى، بيمارىهاى كوارشى، بيمارىهاى خارج كوارشى، فاكتورهاى بيمارىزايى }
$$

كبىرايت (؟ مجله ميكروب شناسى بزشكى ايران: دسترسى آزاد؛ كبى بردارى، توزيع و نشر براى استفاده غيرتجارى با ذكر منبع آزاد است.
اطلاعات مقاله

تاريخجهُ مقاله

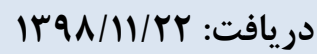

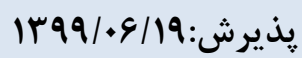

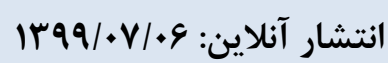

موضوع:باكترى شناسى يزشكى

نويسنده مسئول: مرَّان فروتن، كروه كَوارش، مركز تحقيقات

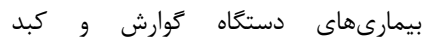
(RCGLD) )، دانشكاه علوم يزشكى شهيد

بهشتى، تهران، ايران

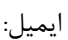
drmojganforootan@gmail.com

مقدمه

با داشتن ويزگى pylori اسيديته را دارد (V،人)). بسيارى از بيمارىهاى دستخاه گوارشى از جمله

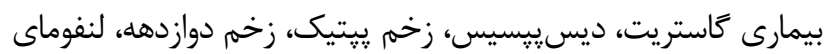
بافت لنفوئيدى همراه مخاط معده Lymphoma) MALT) و آدنو كارسينوما معده به شدت با عفونت حاصل از H. pylori مرتبط است

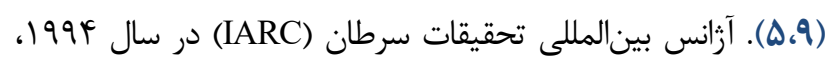
را در گروه اول كارسينوزن H. pylori

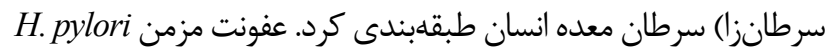
در بافت معده منجر به ايجاد يك محيط سرطانزا يا التهاب مزمن مى -

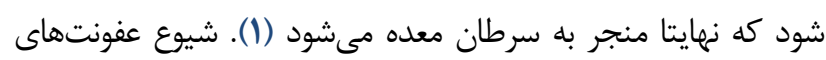
حاصل از اين ياتوزن در كشورهاى مختلف متفاوت است، به عنوان مثال

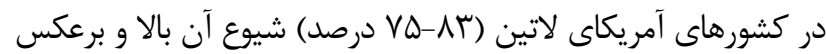

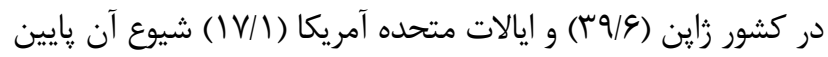
است (9). عفونت H.pylori و انتقال آن با وضعيت اقتصادى -جتماعى إنى
هليكوباكتر بيلورى (Helicobacter pylori or H. pylori)، باكترى گرم منفى مارييجى شكل است كه براى اولين بار در سال r 1919 توسط Rabin Warren Marshall و كه در همان سال جايزه نوبل را دريافت كردند، كشف شد (ا, ץ). اين پاتوزن از لحاظ ايجاد عفونت در انسان به عنوان يكى از موفقترين یاتوزنها شناخته شده كه

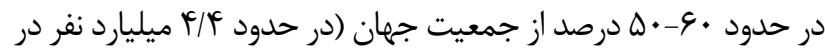

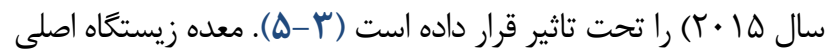
باكترى H. pylori است اما ممكن است زيستخاه آن به دوزادهه يروگزيمال يا ديستال ازوفاگوس در حضور متايلازى معده گسترش ييدا كند (Y). H. pylori به ميزان زيادى جهت حضور در معده انسان سازگار شده است در حالى كه بسيارى از باكترىها توانايى حضور در معده انسان را ندارند. عوامل متعددى از جمله اسيديته، يرستاليس، قابليت

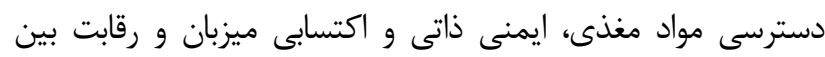
H. ميكروبها، حضور باكترىها را در معده انسان محدود ميى كنندئ 
خارج از دستخاه گوارش با استفاده از كلمات كليدى هليكوباكتر يِيلورى،

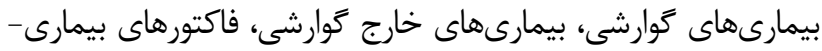

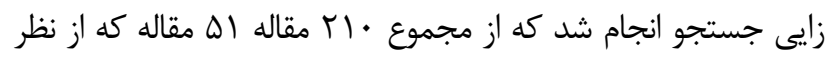

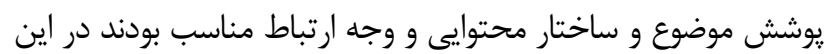
مقاله بررسى شدند.

\section{H.pylori مرورى كلى بر فاكتورهاى بيمارىزايى و عفونت}

يس از ورود به معده ميزبان از فعاليت اورهآز جهت H. pylori

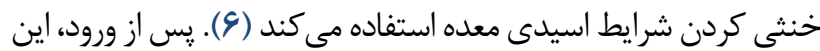
باكترى ممكن است فاكتورهاى بيمارىزايى مرتبط با التهاب و علايم

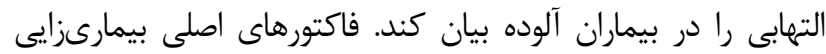
A شامل Fاما تلوتاميل ترانسييتيداز (GGT. pylori وابسته به سيتوتوكسين (CagA) و سيتوتوكسين A واكوئلزا (VacA) كه باعث آسيب به بافتهاى ميزبان مىشود، هستند. محصولات حاصل

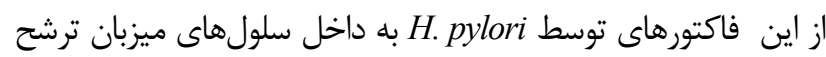
مىشود (r)). مطالعات قبلى تا حدودى نشان داده است كه CagA

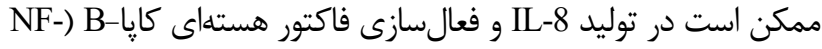
אB نقش مهمى داشته باشد. علاوه بر اين بيان CagA باعث القاى توليد VacA و انتقال NF- IL-8 باكترى H. pylori قادر به القاى واكوئل سازى داخل سلولى در سلول هاى

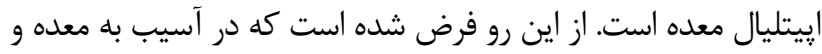
مخاط دوازدهه كه نهايتا منجر به تشكيل زخم باشند، سهيم باشد.

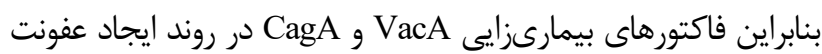
و بيمارىزايى H. pylori نقش بسيار مهمى را ايفا مىكنند (9). فاكتورهاى ديكر از جمله فاكتور خسبان Bab2، بروتئين التهابى بيرونى

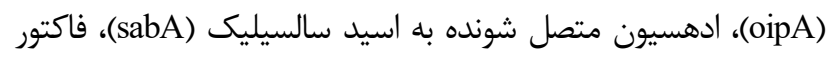
iceA مخاطى موثر هستند. علاوه بر اين فاكتورها در روند بيمارىزايى لايه دايه

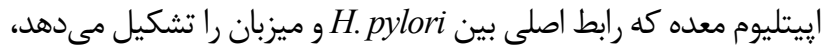
سايتوكاين ها (Cytokine) را براى شروع ايمنى ذاتى و فعالسازي نوتروفيلها ترشح مى كند و نهايتا منجر به بيمارىهاى بالينى مانند كاستريت و زخم مىشود. به صورت خلاصه جهار مرحله جهت استقار إنقار و بيمارىزاى H. pylori ضرورى است: ا - بقا در شرايط اسيدى معده

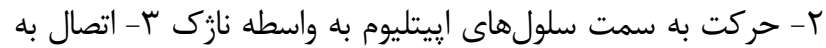

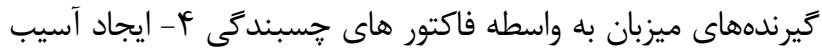

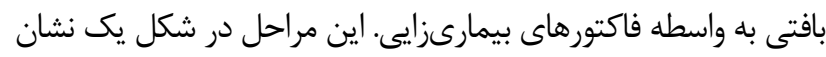

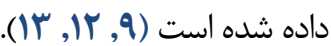

ضعيف مانند بهداشت ضعيف، آلودگى آب، سبك زندگى غلط، رزيم غذايى ضعيف، استعمال دخانيات و عدم فعاليت فيزيكى ارتباط دارد (().

H. pylori نتايج حاصل از مطالعات مختلف نشان داده است كان همجنين با بيمارىها و اختلالهاى خارج كوارشى مرتبط است. اولين كروه از اين بيمارىها يروفايلهاى متابوليكى غير معمول از جمله مقاومت إنات

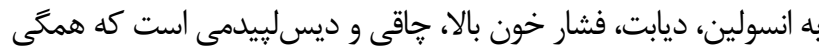

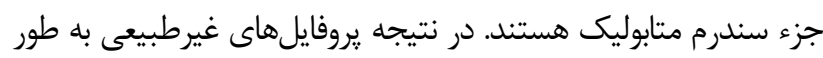
بيجيدهاى منجر به افزايش خطر بيمارىهاى قلبى-عروقى به وسيله

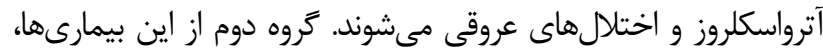

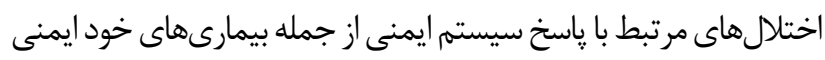

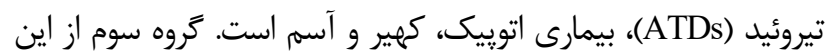

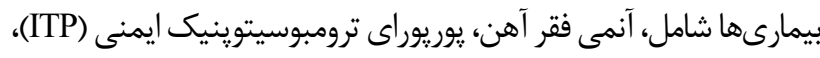

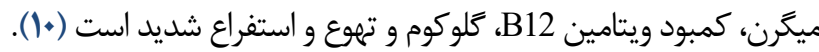
مكانيسم يِيشنهادى براى اين بيمارىها به اين صورت است كه عفونت

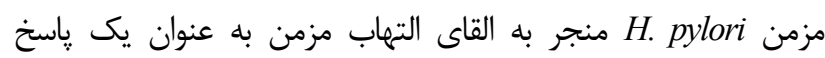
بيولوزيكى يبجيده بافتى مىشود. فاكتورهاى التهابى از جمله سيتوكينز

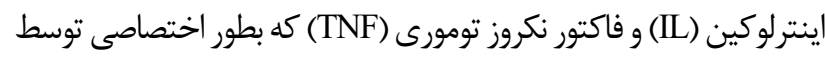

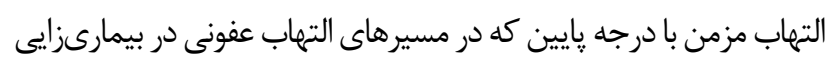

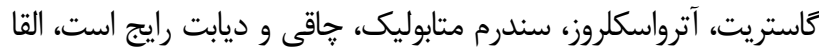

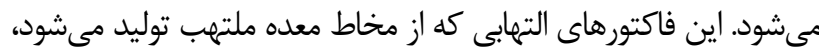
به صورت بيوسته به داخل كردش خون ترشح مىشود و از اين طريق

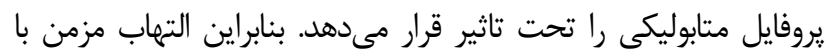
درجه بايين توسط عفونت H. pylori ممكن است باعث القاى بيمارى هاى

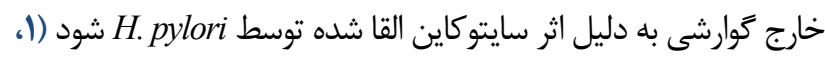
•(1) (1). مطالعات متعدد در سالهاى اخير نشان دهنده اهميت مطالعه H. pylori بيمارىهاى گوارشى و خارج گوارشى مرتبط با عفونتهان است. تيم تحقيقاتى ما در اين مقاله مرورى مهمترين بيمارىهاى مرتبط با عفونت H. pylori (بخصوص بيمارىهاى خارج توارشى مرتبط بار با آن)

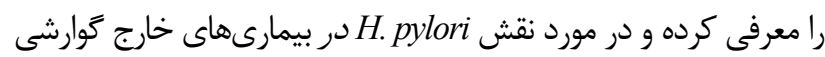

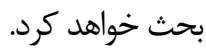

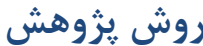

مطالعه حاظر با هدف بررسى ارتباط هليكوباكتر بيلورى با عفونت هاى خارج از دستكاه كوارش به كمك طبقه بندى موضوعات تحقيق

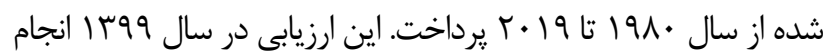

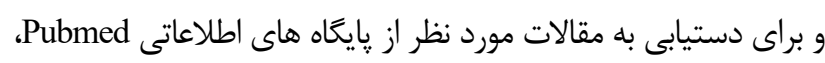
(Iranmedex ،WHO Cochran Library ،Medline

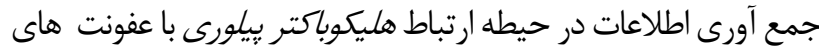




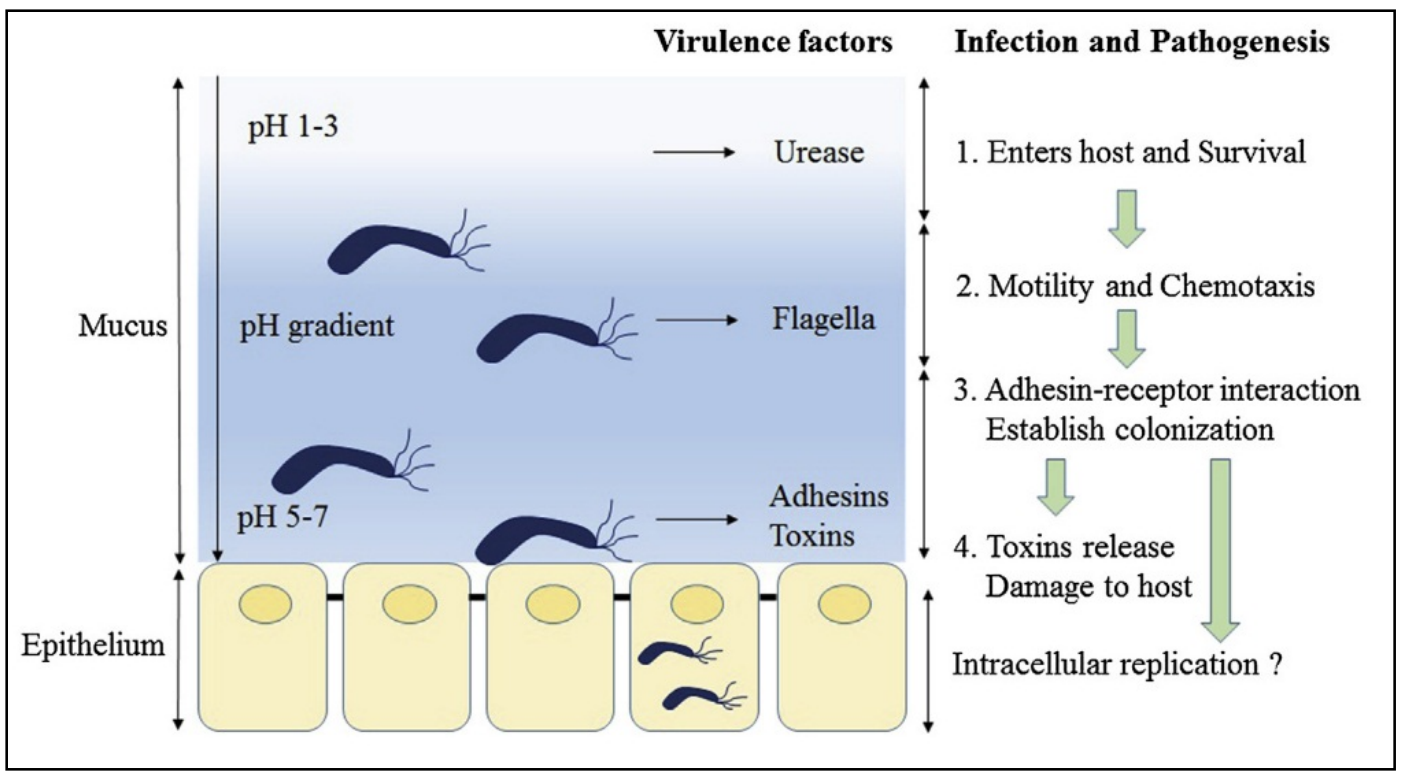

(9) H. pylori شكل ا. دياكرام شماتيك از بيمارىزايى و عفونت

\section{إييدميولوزى و تاريخجه طبيعى}

سير بالينى عفونت H. pylori بسيار متغير بوده و تحت تاثير

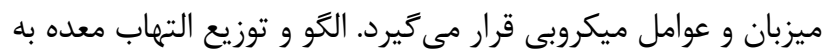
شدت با خطر عواقب بالينى يعنى زخمهاى دوازده و معده، اتروفى ماري

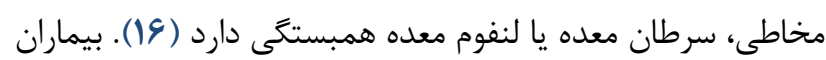
مبتلا به آنترال-يرهدامينانت كاستريت، شايعترين نوع كاستريت H. pylori

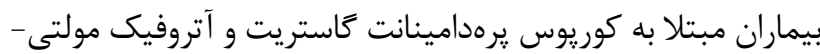

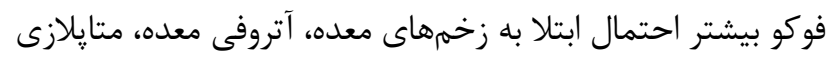
روده و در نهايت سرطان معده را دارند. آندروكارسينوما معده بر اثر آثراي عفونت H. pylori به ترتيب از التهاب معده شروع شده و نهايتا به

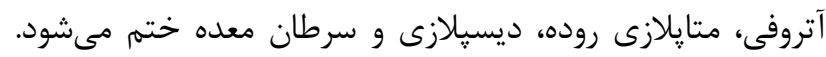
H. pylori

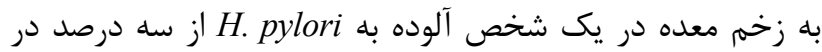

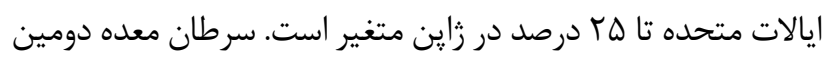
علت مرك و مير ناشى از سرطان است. شواهد زيادى مبنى بر اينكه

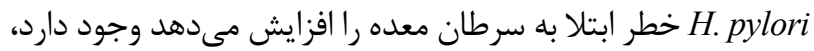
بطورى كه در سال 1994 به صورت قطعى به عنوان كارسينورن نوع

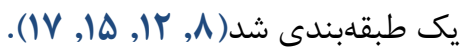

كاهش يُيوسته شيوع عفونت H. pylori و بروز سرطان معده در بيشتر جمعيتها به خصوص در جوامع ثروتمند غربى در دهلهاى

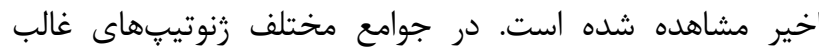
باكتريايى نيز بسيار متفاوت است. جوامعى كه ريسك ابتلا به سرطان معده بالاترى را نسبت به جوامع ديگر دارند، سويههاى داراى قدرت بيمارىزايى بالاتر را در خود جاى دادهاند (IF). در بعضى از افراد بيشتر از يك سويه كه دارى قدرت بيمارىزايى متفاوتى هستند در

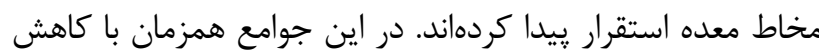
نرخ سرطان و شيوع عفونت تغييرات بزرگ از جمله توسعه اقتصادى

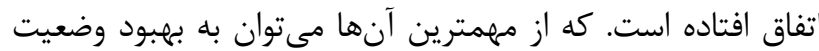

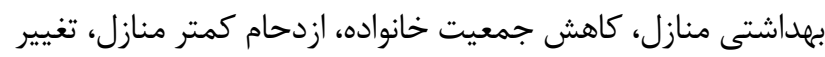
در عادت غذايى از جمله مصرف كمتر نمك و مصرف بيشتر سبزيجات تازه و ميوه، بهبود وسايل سرمايشى و كنترل بيمارىهاى

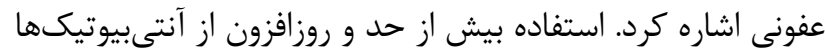
براى درمان ديخر بيمارىهاى عفونى ممكن است اثار ناخواسته بر آند

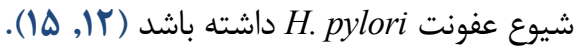



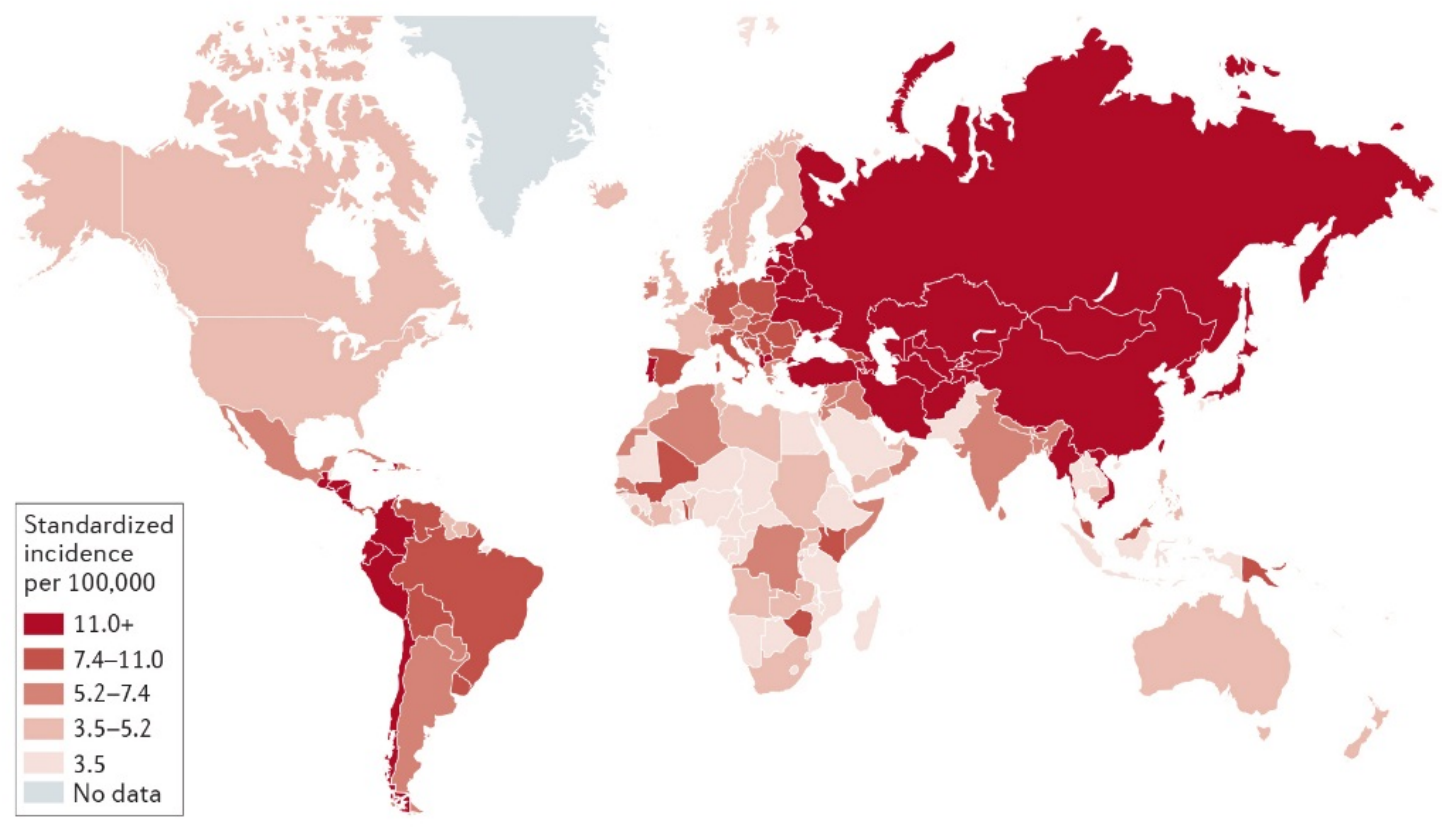

شكل r. شيوع سرطان معده در سال r . r (A).

ديواره يا لنفادنوياتى)، به احتمال زياد نيازمند درمان لنفوم هستند.

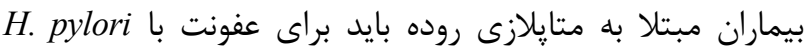

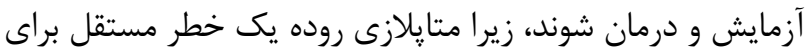

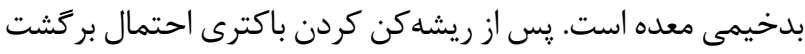

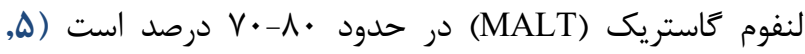
$(\Lambda, 1 \mathrm{r}, 1 \mathrm{~d}$
مطالعات نشان داده كه تقريبا تمامى بيماران مبتلا به لنفوم Fاستريك MALT آلوده به H. pylori بودهاند، يعنى عفونت حاصل از H. pylori بطور قابل توجهى خطر ابتلا به لنفوم

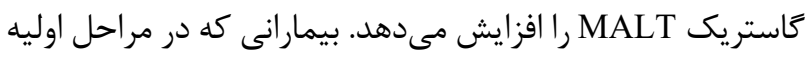

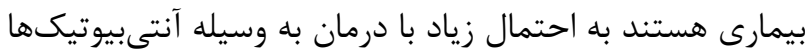
بصورت كامل بهبود پِيدا كنند، اما افرادى كه در مراحل بِيشرفته

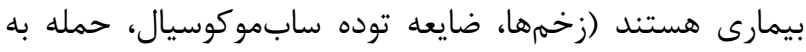

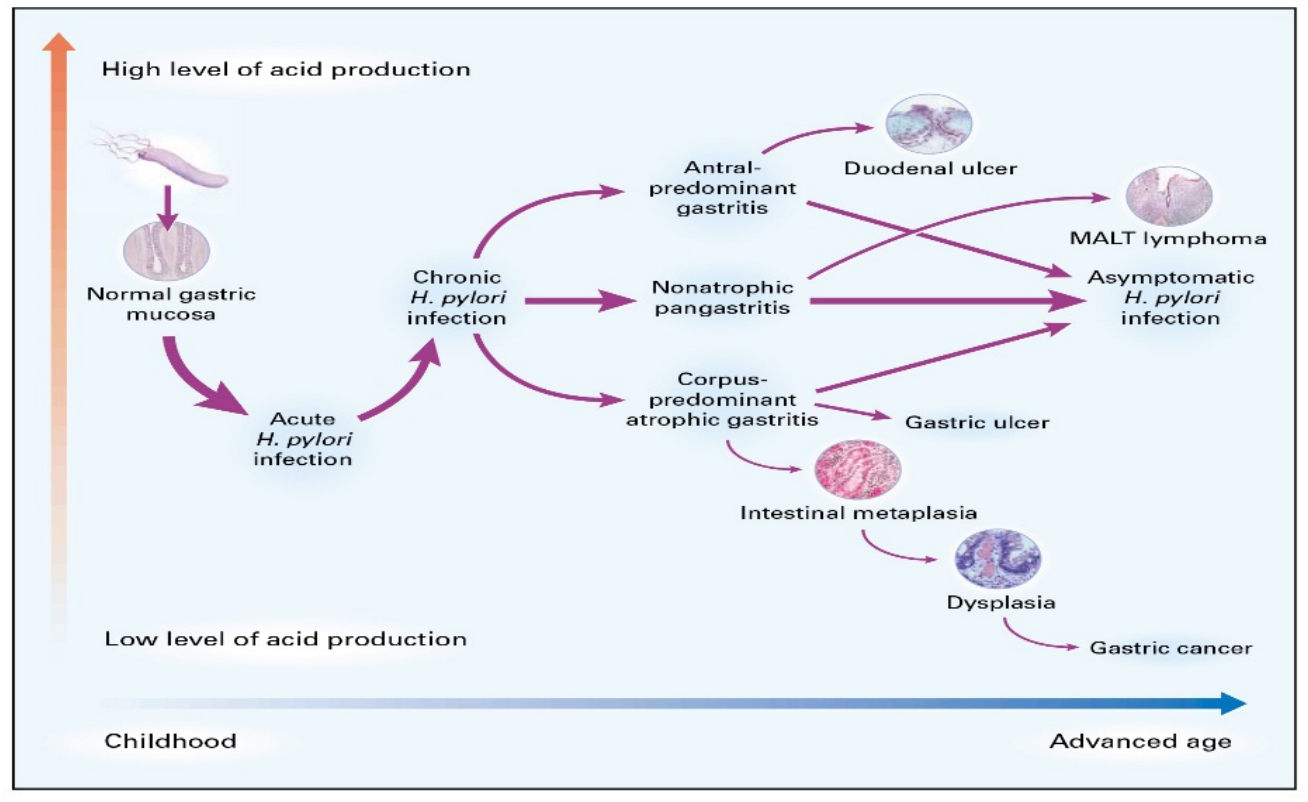

شكل r. سير طبيعى عفونت (IV) H. pylori. 
نوروزنيك، تنفسى و ساير اختلالها در ارتباط باشد. مكانيسمهاى

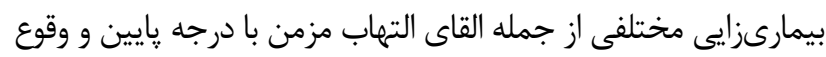

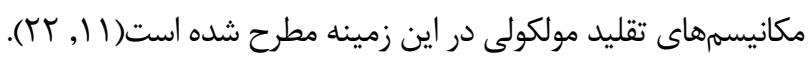

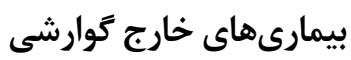 بيمارىهاى قلبى -عروقى}

مقالهاى كه اخيرا توسط Wang و همكاران (Y) • (广) منتشر شده، ارتباط بين عفونت H. pylori و خطر ابتلا به بيمارىهاى قلبى -عروقى أنى

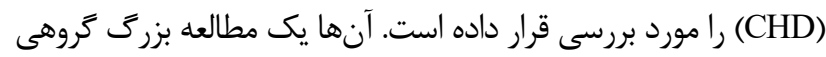

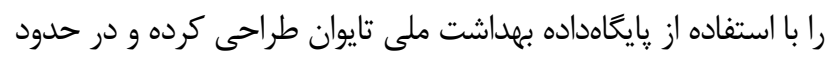

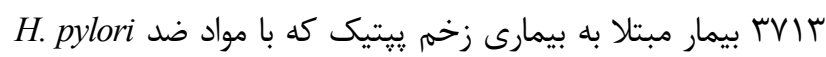

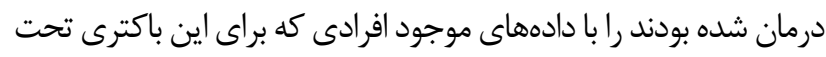

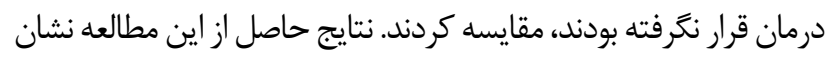

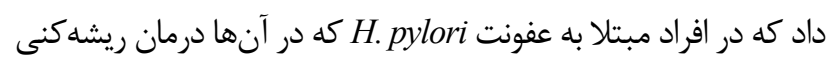

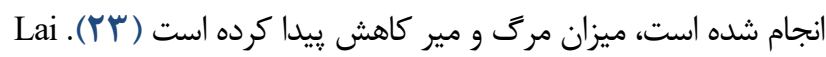

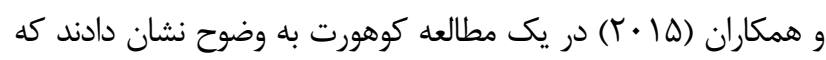

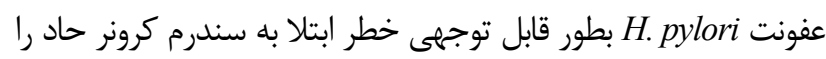

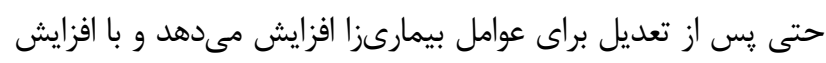

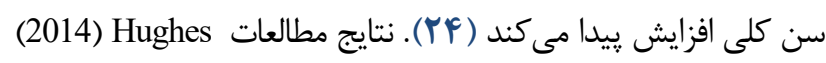

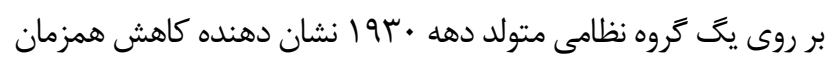

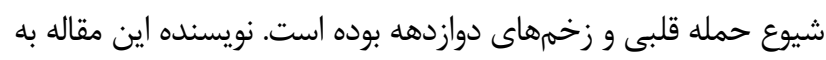

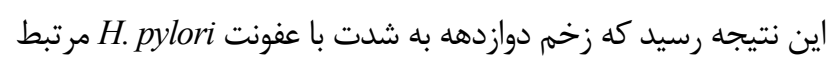

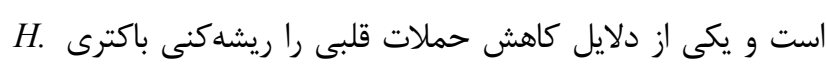
pylori

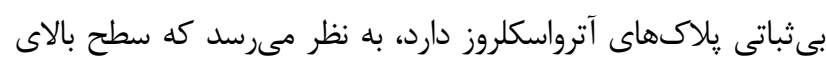

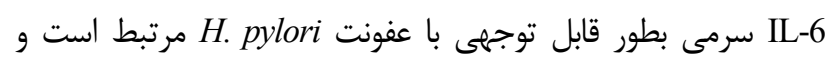

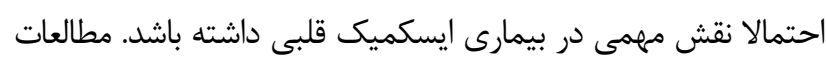

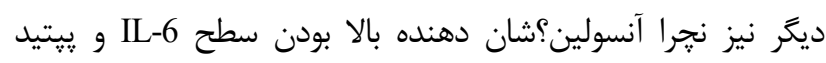

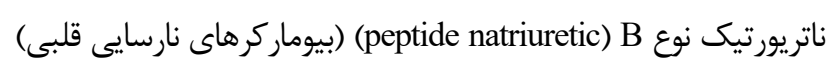
در خون بيماران مبتلا به بيمارى عروق كورنر كه به سويههاى مثبت

CagA

\section{ديابت و مقاومت به انسولين}

مقاومت به انسولين (IR) يكى از مهمترين عوامل بيمارىزايى

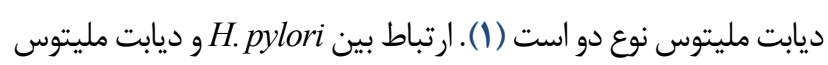

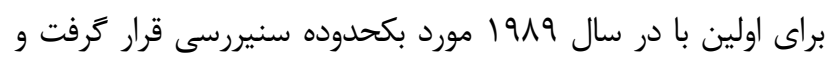

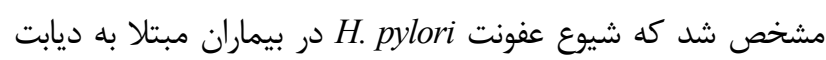

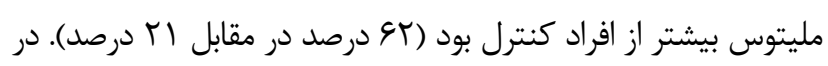

تخمين زده شده كه در حدود ه درصد از افراد مبتلا به ديس-

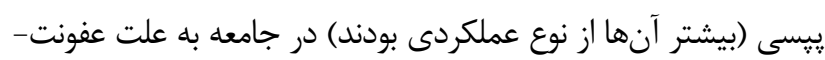

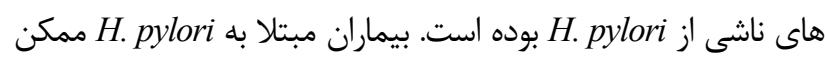

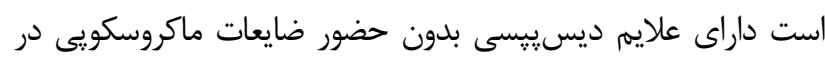

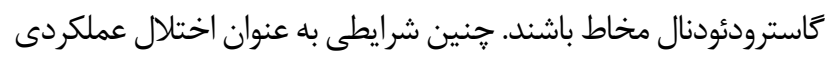
ديسيسيى شناخته شده و مكانيسمهاى مختلف ياتوزئن

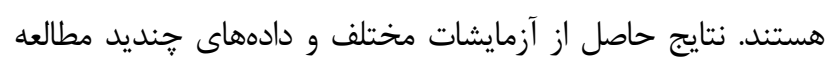

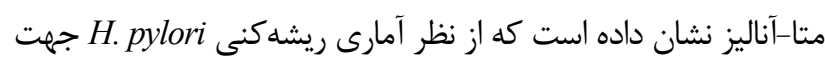

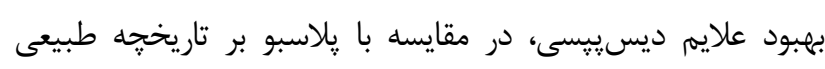

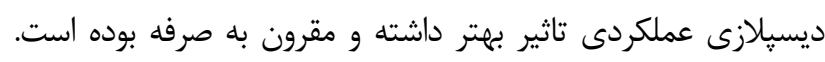

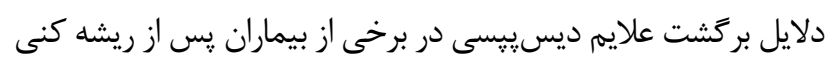
هنوز بطور كامل مشخص نشده است (1) pylori بيمارى رفلكس معده (GERD) يك اختلال جند فاكتورى است كه منجر به ريفلاكس اسيد معده به داخل مرى شده و منجر بله به آسيب

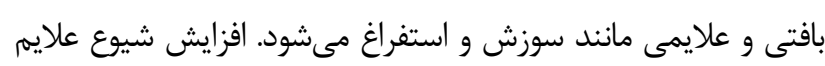

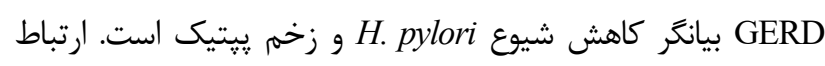

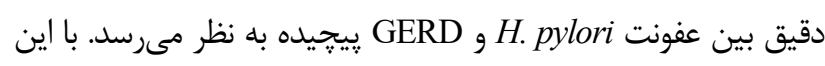

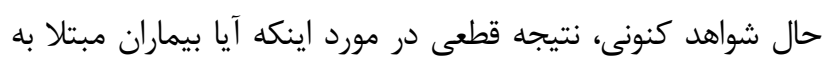

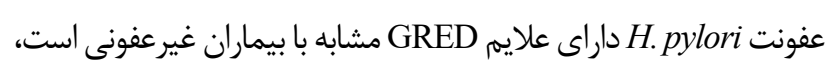

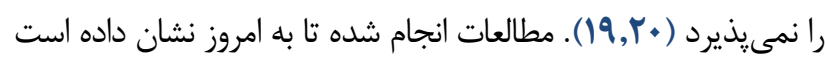

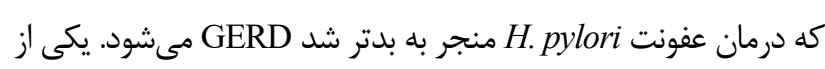

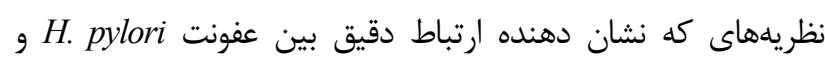
GERD

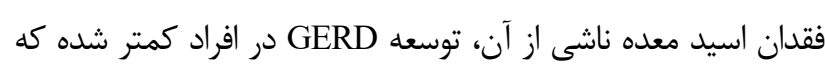
يك خطر بالقوه براى بيمارى مرى بارت و آندوكارسينوماى مرى است است.

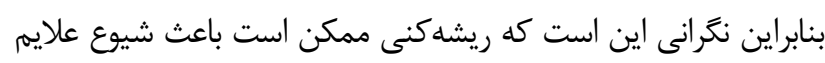
GERD

سراسر جهان شود (I) (1) - (1).

بيمارىهاى خارج گوارشى مرتبط با عفونت H. pylori در جند

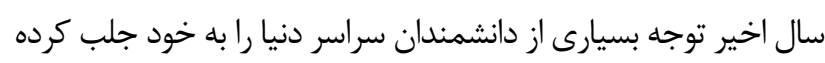
است. در حقيقت H. pylori ممكن است با بسيارى از فرائ فرايندهاى

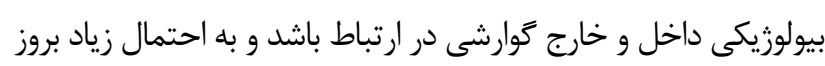

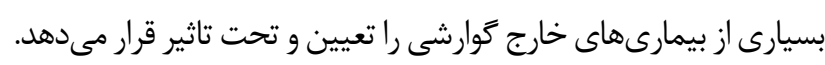

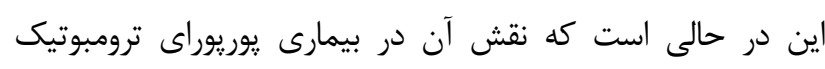

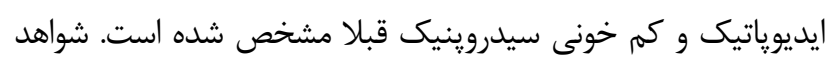
تازه نشان مىدهند كه H. pylori ممكن است خطر ابتلا به به سندروم

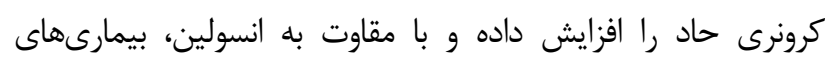




\section{سندرم متابوليك (MetS)}

سندرم متابوليك (MetS) با مجموعداى از اختلالهاى

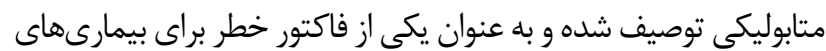
مختلف دستكاه توارشى و همجنين بيمارىهاى قلبى -عروقى در نظر

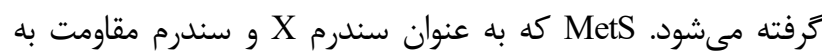

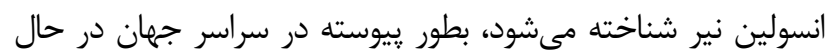

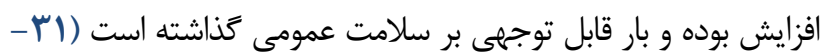

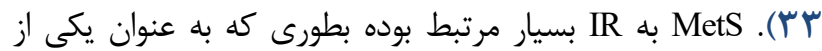

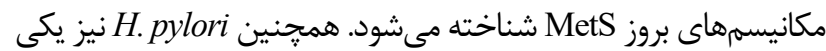

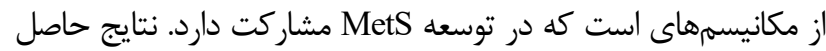

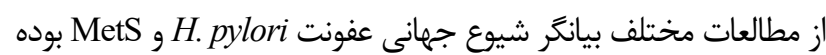

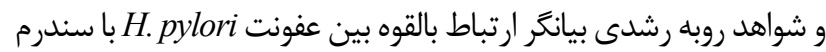
MetS و و IR

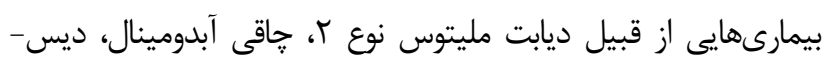
لييدمى، فشار خون بالا، بيمارى كبدى خربى غيرالكلى (NAFLD) و بيمارىهاى قلبى عروقى بوده (Nonalcoholic fatty liver disease)

Nabipour ارتباط بين عفونت MetS و He pylori را مورد ارزيابى قرار دادند. نتايج

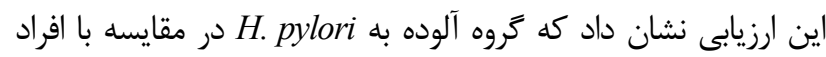

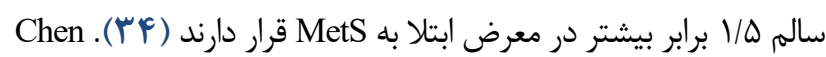
و همكاران (لا •r) با استفاده از تست تنفسى اوره و تشخيص

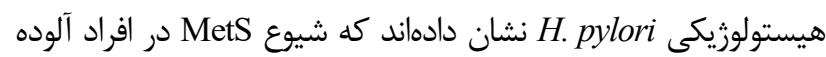

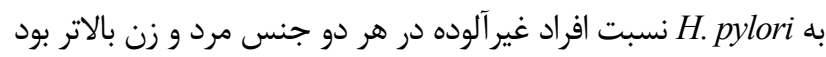

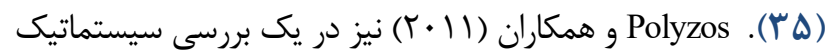

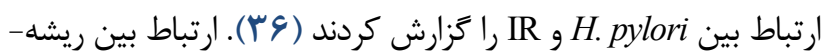
H. pylori بو بركشت MetS به منظور ارزيابى اثر عفونت بر بيمارىزايى MetS در ميان سياه يوستان مورد بررسى قرار كرفت.

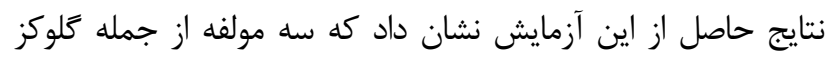

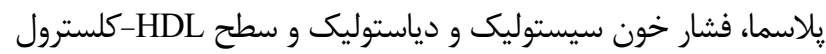
در مقايسه با مقادير קايه پِ از سه هفته از ريشه كنى H. pylori بهبود

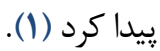

مقاله مرورى تحت عنوان "نقش احتمالى عفونت H. pylori در بيمارى NAFLD كه توسط Chen و همكاران (YlV (r) در سالهاى اخير هاب شده است به خوبى نشان دهندهى مكانيسمى است كه

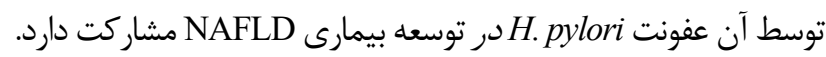
IR به عنوان بخش مهمى از توسعه بيمارى NAFLD در نظر كرفته

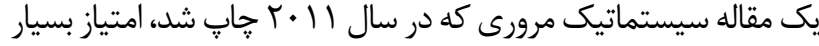

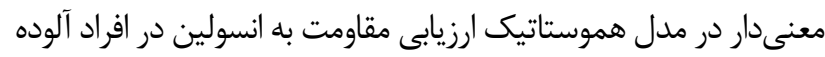
به عفونت H. pylori نسبت به افراد غير آلوده در هفت آناليز مقطعى

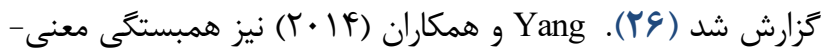

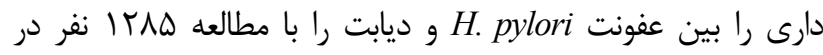

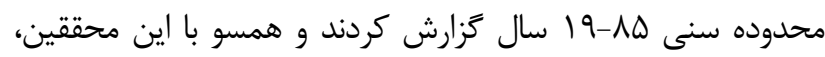
H. نتايج مشابهى توسط محققين هندى كزارش شد (YV) به طور معنى دارى باعث بدتر شدن كنترل كليسميك در بيماران مبتلا به ديابت مىشود. علاوه بر اين محققين ديكرى به منظور درك برى برد

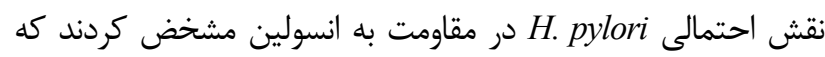

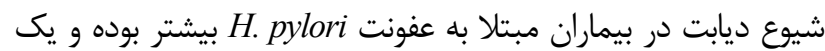
همبستگى مثبت بين عفونت H. pylori با مقاومت به انسولين وجود

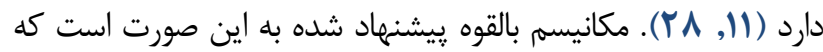

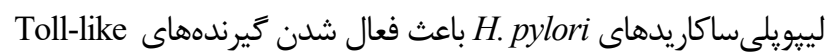
receptor شده و متعاقبا منجر به برداشت انرزى، تجمع تربى و در نهايت مىشود. در التهابهاى شديد، سيتوكينها اثر انسولين بر خيرنده خود را از طريق فسفريلاسيون رزيديو سرين در كيرنده انسولين مهار كرده و

متعاقبا منجر به مقاومت و عدم حساسيت به انسولين مىشوند (1). على رغم وجود ارتباط معنىدار بين عفونت H. pylori و ديابت اما بين محققين بر سر اين موضوع اختلاف نظر وجود دارد. دليل اين اختلاف نظر نتايج متفاوت در مقايسه سطح ديابت قبل و بعد از ريشهكنى H. pylori در آزمايشات مختلف است. آزمايش مختلفى وجود دارد

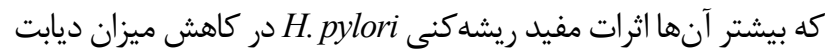

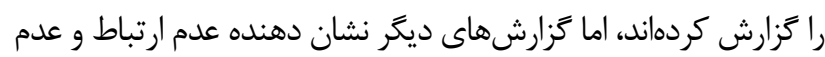

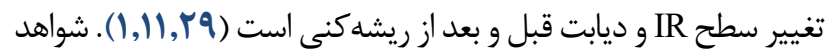
متعددى مبنى بر افزايش حساسيت به عفونت در بيماران ديابتى است.

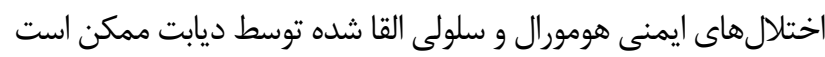

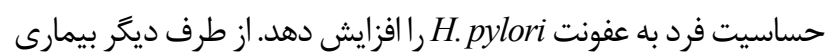
ديابت باعث كاهش ميزان تحركات گوارشى و ترشح اسيد شده كه اين امر ممكن است باعث ارتقاء كلونيزاسيون H. pylori و ميزان عفونت در

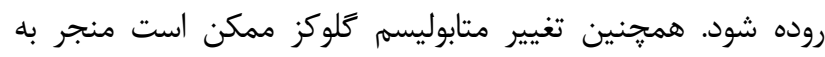
تغييرات شيمايى در موكوس كاستريك شده كه متعاقب آن كلونيزاسيون H. pylori ارتقا بِيدا مى كند. علاوه بر اين افراد مبتلا به

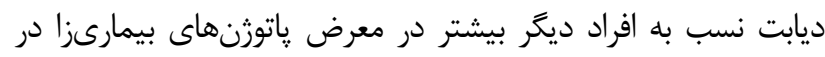

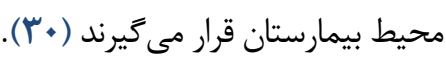


كبد شده و در نتيجه رسوب جربى و VLDL-C (SCDI) كبدى را تسريع مى كند (شكل ؟ا). با توجه به تعامل روده و معده، عفونت H. pylori Chen

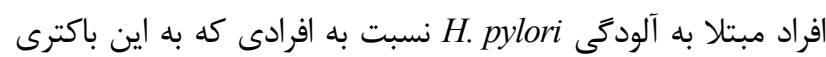

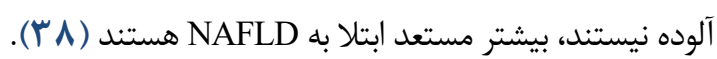

H. شده و مطالعات بسيار زيادى نيز تاييد كننده نقش مهرم عفونت

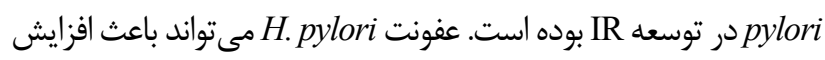
التهاب مزمن با درجه يايين شده و سطح فاكتورهاى ضدالتهابى از جمله

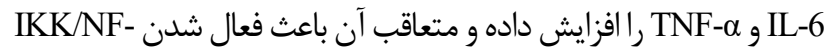

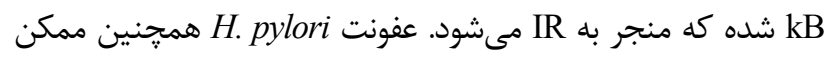
است بافت جربى سفيد را براى آزادسازى لهتين مهار كند كه منجر به افزايش فعاليت دساجوراز استرويل- desaturase CoA stearoyl) CoA

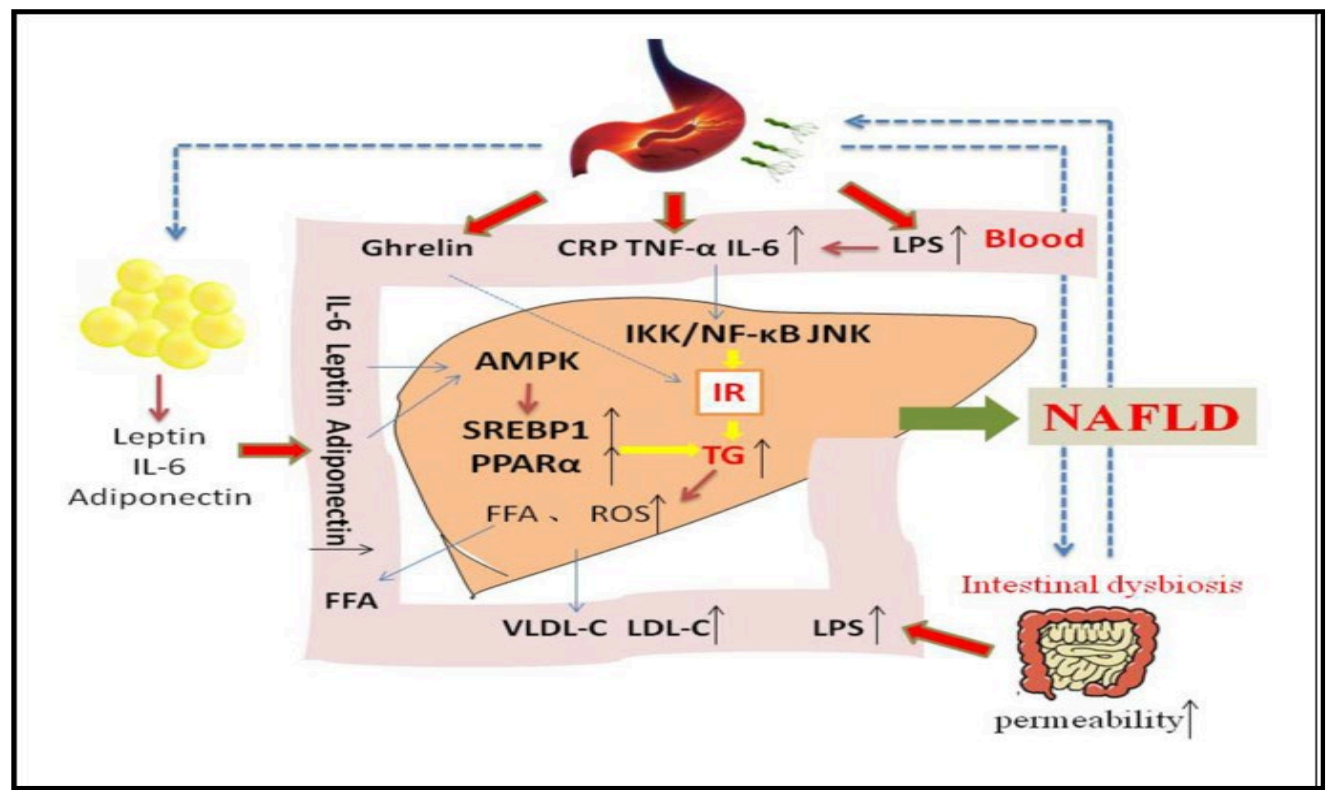

شكل F. نقش احتمالى عفونت H. pylori در بيمارى Y^ NAFLD).

\section{Proposed entrance of $\mathrm{Hp}$ in $\mathrm{CNS}$}

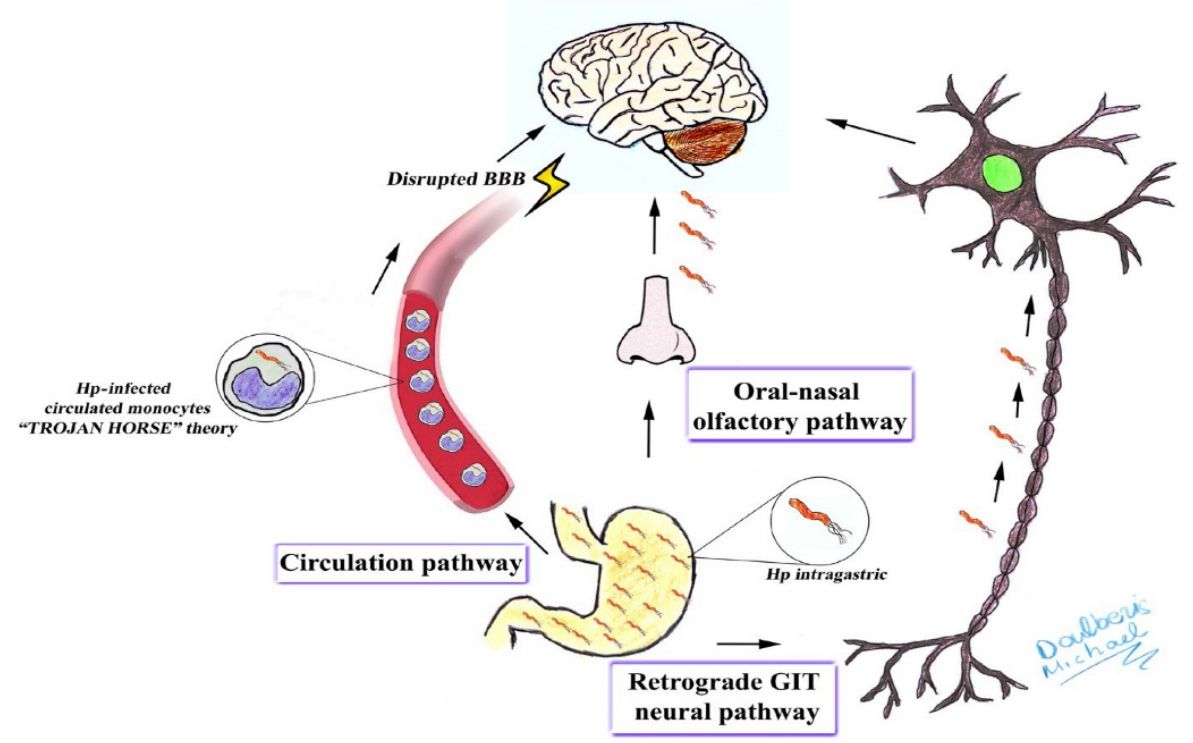

شكل ه. نمايش شماتيك از سه تئورى كه بطور مكانيكى امكان ورود H. pylori ا به CNS توضيح مىدهد (•F). 


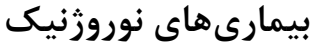

بطور انتخابى بر روى اعصاب بينايى و طناب نخاعى تاثير مى گذارد.

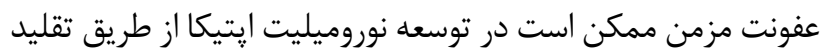
مولكولى بين AQP4-انسانى و AQP4-باكتريايى تاثير بخذارد. علاوه

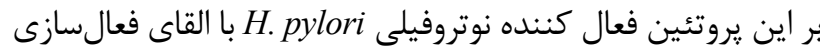

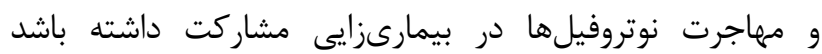

(FY, FF)

\section{سكته مغزى ايسكميك}

با توجه به نتايج حاصل از مطالعت مختلف به نظر مى -

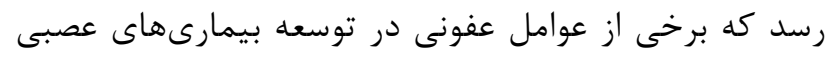

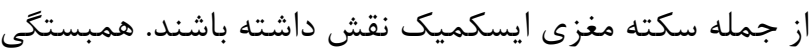
مثبت و معنى دارى بين عفونت H. pylori و سكته مغزى وجود

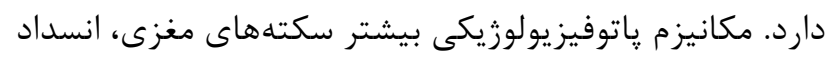

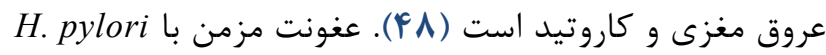
و حضور سويههاى مثبت CagA يك ريسك فاكتور معنى براى سكته مغزى است. به طور مشابه سويههاى CagA-مثبت H. pylori بيماران مبتلا به عفونت فعال مرتبط است. مكانيسم خطر بالي بالاى سكته مغزى ايسكميك با عفونت مزمن H. pylori هنوز

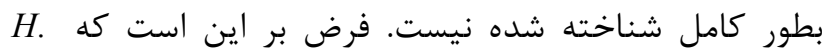

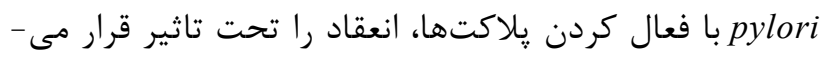
دهد. بر اساس نتايج حاصل از مطالعات مختلف نشان داده شده كه شش ماه يس از ريشهكنى عفونت H. pylori، سطح

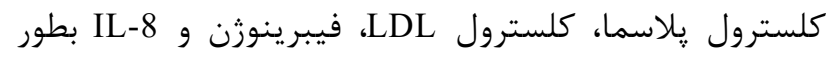

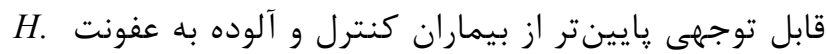
pylori

\section{بيمارى هاى هماتولوزيك}

\section{آنمى فقر آهن (IDA)}

ارتباط بين آنمى فقر آهن (IDA) با عفونت H. pylori به خوبى مشخص شده است. در سال 199 ارباى اولين بار Blaser و ا همكاران ارتباط بين كاستريك همورازيك و عفونت H. H. pylori

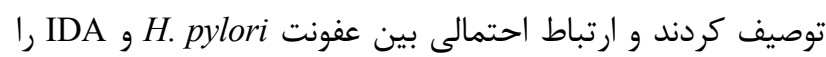

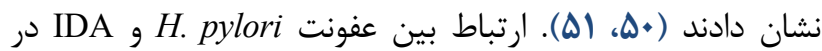
كودكان و بزرَسالان در مطالعات مختلفى تاييد شده است (•ه-

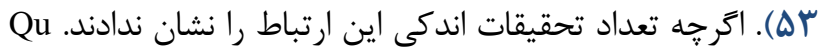

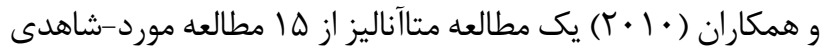

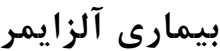

آلزايمر به ويزه در كشورهاى صنعتى شايعترين شكل زوال عقل است كه حدود · † ميليون نفر در سراسر دنيا را تحت تاثير قرار داده است (•). بيمارى آلزايمر يك بيمارى ييشرونده نوروزنيك است كه با تلفات سينايسى و مرك عصبى در نتيجه تجمع خارج

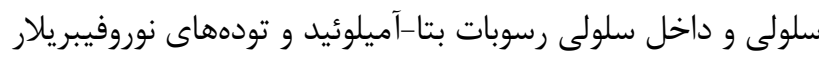
در ناحيههاى از مغز كه جهت حافظه و فرايندهاى شناختى مهرم

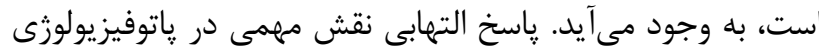

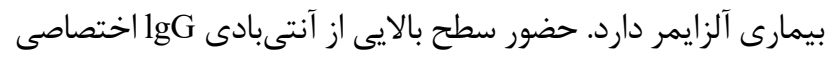

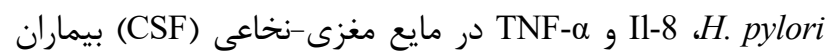

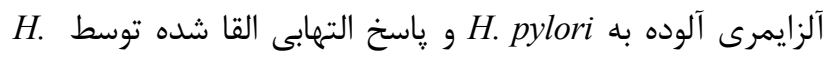
pylori اين اطلاعات با نتايج حاصل از برخى مطالعات كه بهبود وضعيت دهنيت يارامترهاى عملكردى، وضعيت شناختى و ميزان بقا بيماران آلزايمرى را پِ إمترهاي عمكردي، ريشهنى H. pylori مشاهده كردند، مطابقت

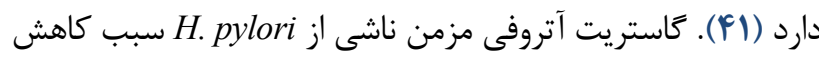
ميزان غلظت ويتامين B در سرم و در نتيجه افزايش غلظت هموسيستئين مىشود. غلظت هموسيستئين سرم با شدت زوال عقل همبستگى دارد. هموسيستئين باعث القاى آسيب اكسيداتيو

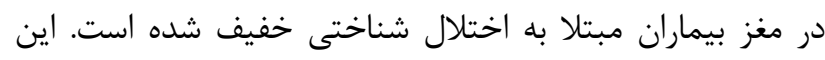

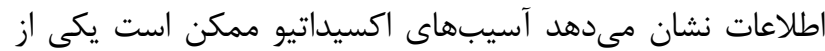
اولين وقايع شروع و يِشرفت بيمارى آلزايمر باشد (FI,FF).

\section{بيمارى مالتييل اسكلروزيس}

بيمارى مالتييل اسكلروزيس (MS) يك بيمارى يِيجيده،

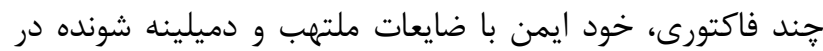
سيستم CNS است. اتيولوزى بيمارى MS هنوز به طور كامل بال

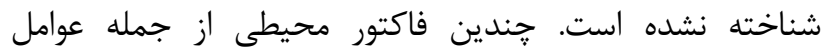

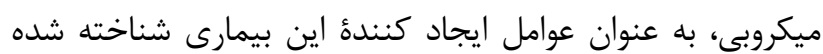
است. در ميان عوامل ميكروبى، H. pylori به عنوان عامل ميكروبى

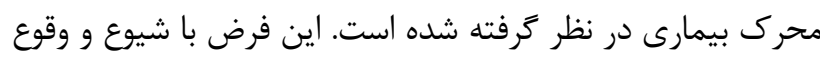

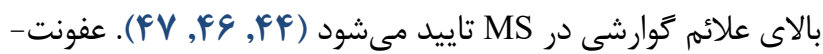
هاى H. pylori به عنوان يكى از ريسك فاكتورهاى توسعه آنتى -

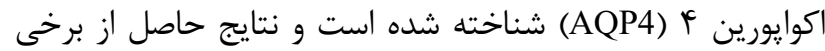

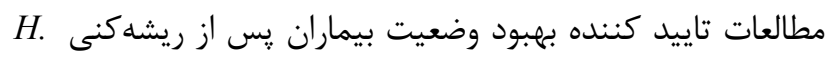

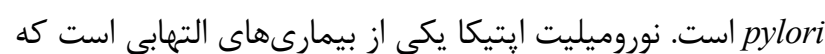


توليد شده است كه با H. pylori و آنتىزن هاى سطح بلاكت -

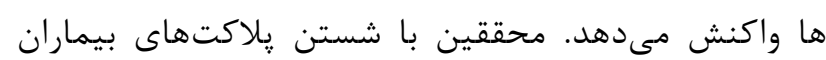

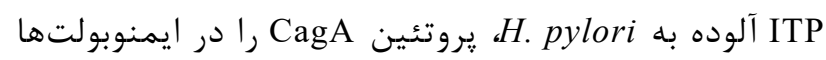

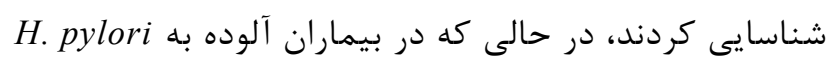

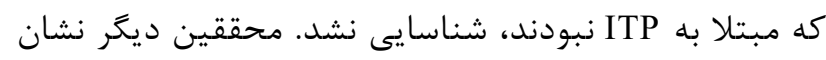
دادند كه آنتىبادىهاى منوكلونال توليد شده برعليه اورهآز GP IIb/IIIa بان H. pylori

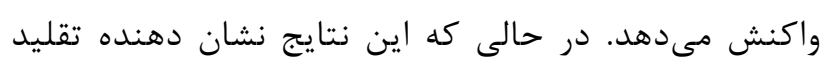

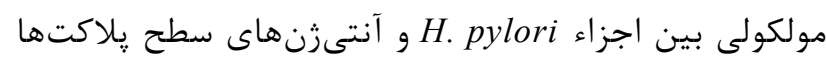

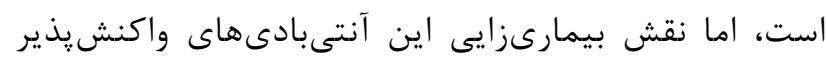

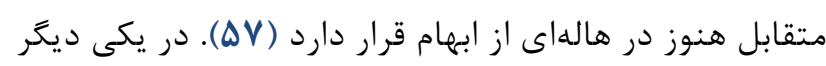

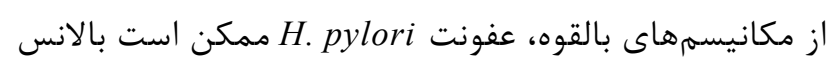

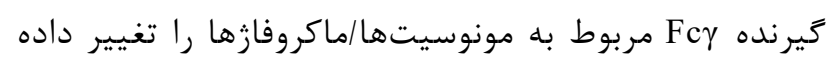
و باعث تشكيل اتوآنتىبادىها شود. مطالعه اخير نشان داده موند

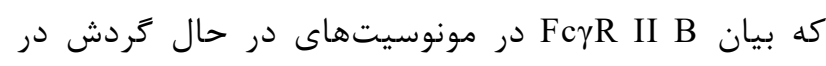

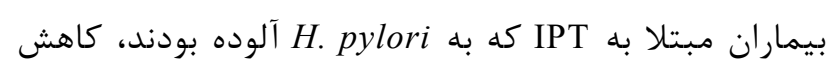

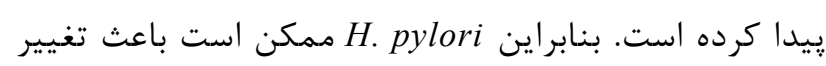

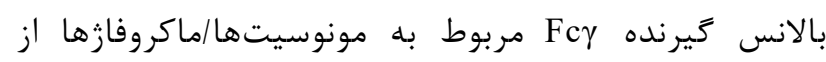
طريق تنظيم كاهشى شود (هI).

\section{كمبود ويتامين B12}

ويتامين B12 كوآنزيم بسيارى از واكنشهاى مههم آنزيمى

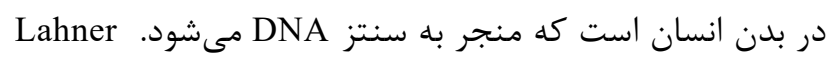

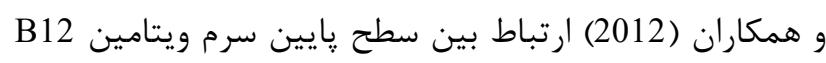

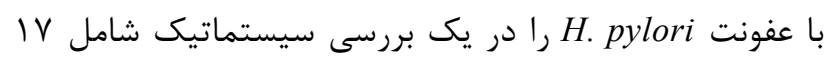
مطالعه با TFAF ب بيمار، نشان دادند. هموسيستئين يكى از اجزاء

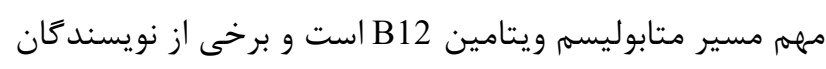

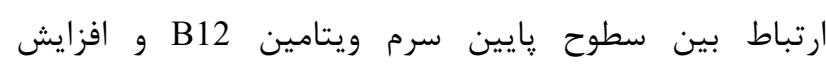

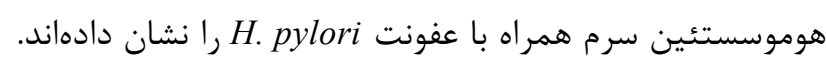

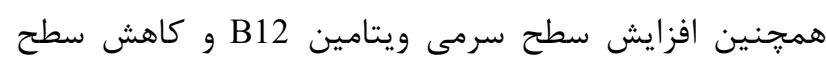

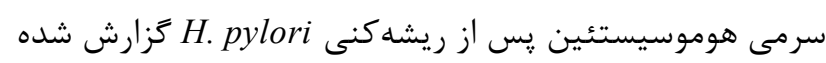

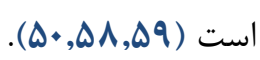

همانطور كه در قسمت هاى قبل توضيح داده شد عفونت H. pylori

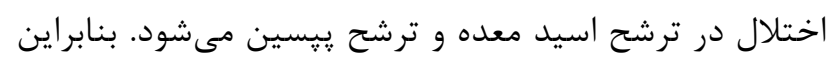

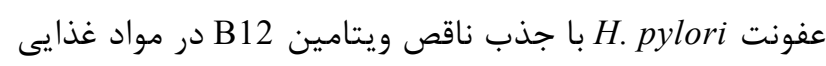

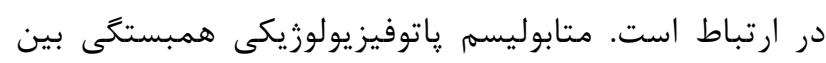

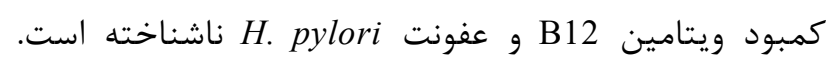

به منظور بررسى ارتباط بين عفونت IDA و H. pylori انجام دادند. در ه مطالعه عفونت H. pylori توسط آندوسكويى و آزمايشات هيستولوزيكى تشخيص داده شده بود كه در آن بيماران مبتلا به مبه

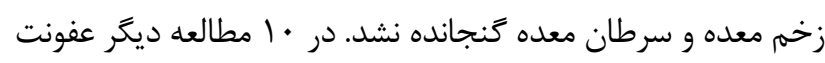

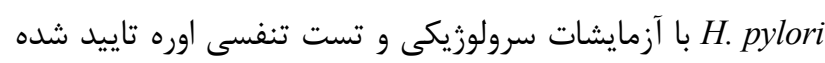

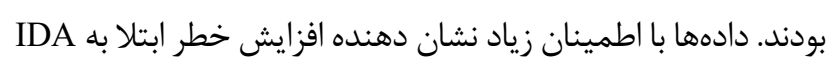

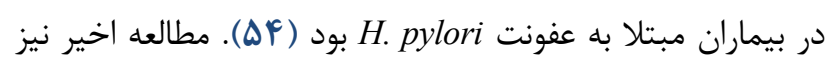

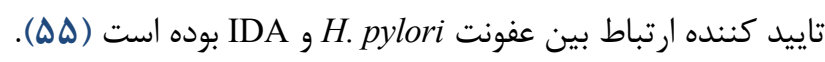

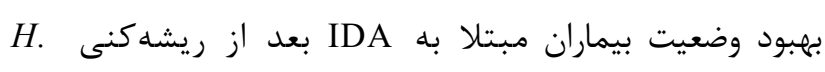

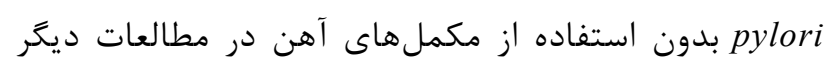

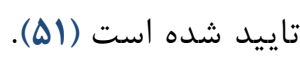

از طر H. pylori

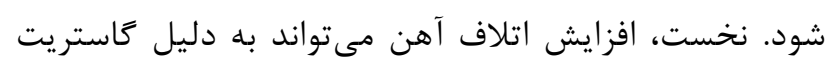

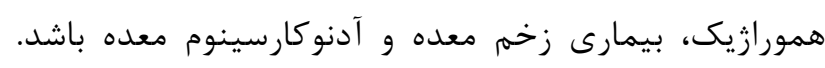
H. pylori بانيا مشخص شده است كه يروتئين

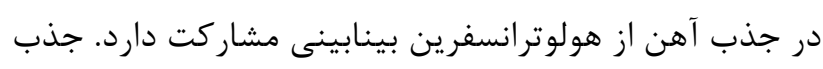

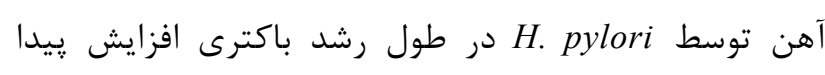

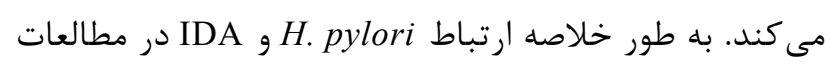
مختلف ثابت شده است و در حال حاضر دستور العمل هاى بين - ماصل

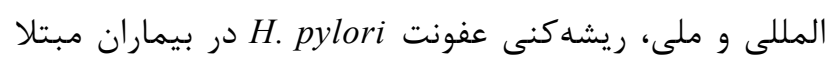

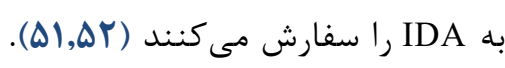

\section{يوريوراى ترومبوسيتو ينيك ايمنى (ITP)}

يوريوراى ترومبوسيتوينيك ايمنى كه قبلا به اسم ايديوياتيك ترومبوسيتوينيك يوريورا و يوريوراى ترومبوسيتوينيك اتوايميون

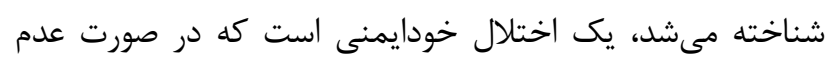

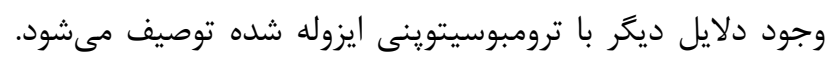

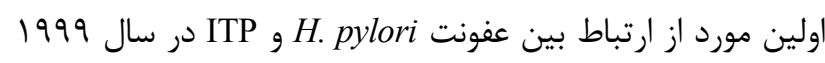

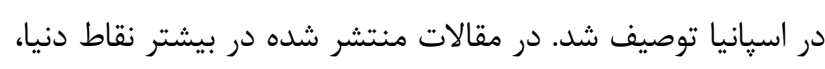

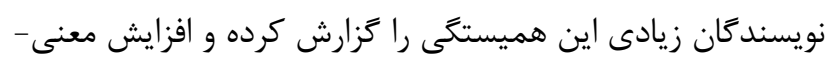

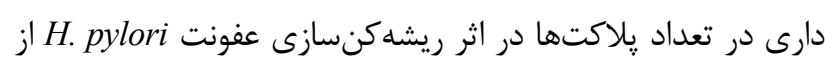

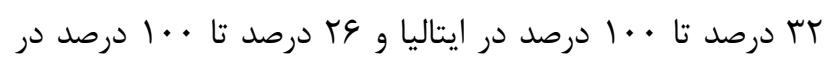

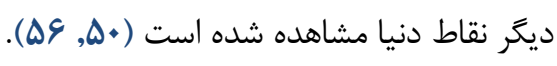
H. pylori تاثير قرار مى دهد. يك فرضيه جذاب درباره تقليد مولكولى إنى

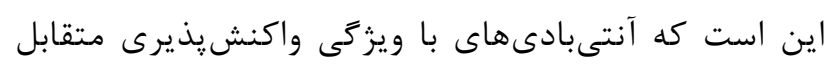


منجر به ارتباط بين ITP Iron Deficiency Anemia) IDA) و و كمبود (Idiopathic Thrombocytopenic Purpura) ويتامين B12 با عفونت H. pylori مى شود در شكل 9 خلاصه شده است.
بيمارى ين گاستريت مرتبط با عفونت H. pylori منجر به تخريب سلولهاى ياريتال معده شده كه متعاقبا سطح

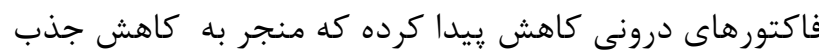

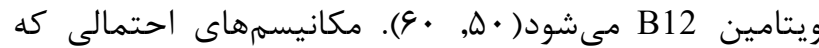

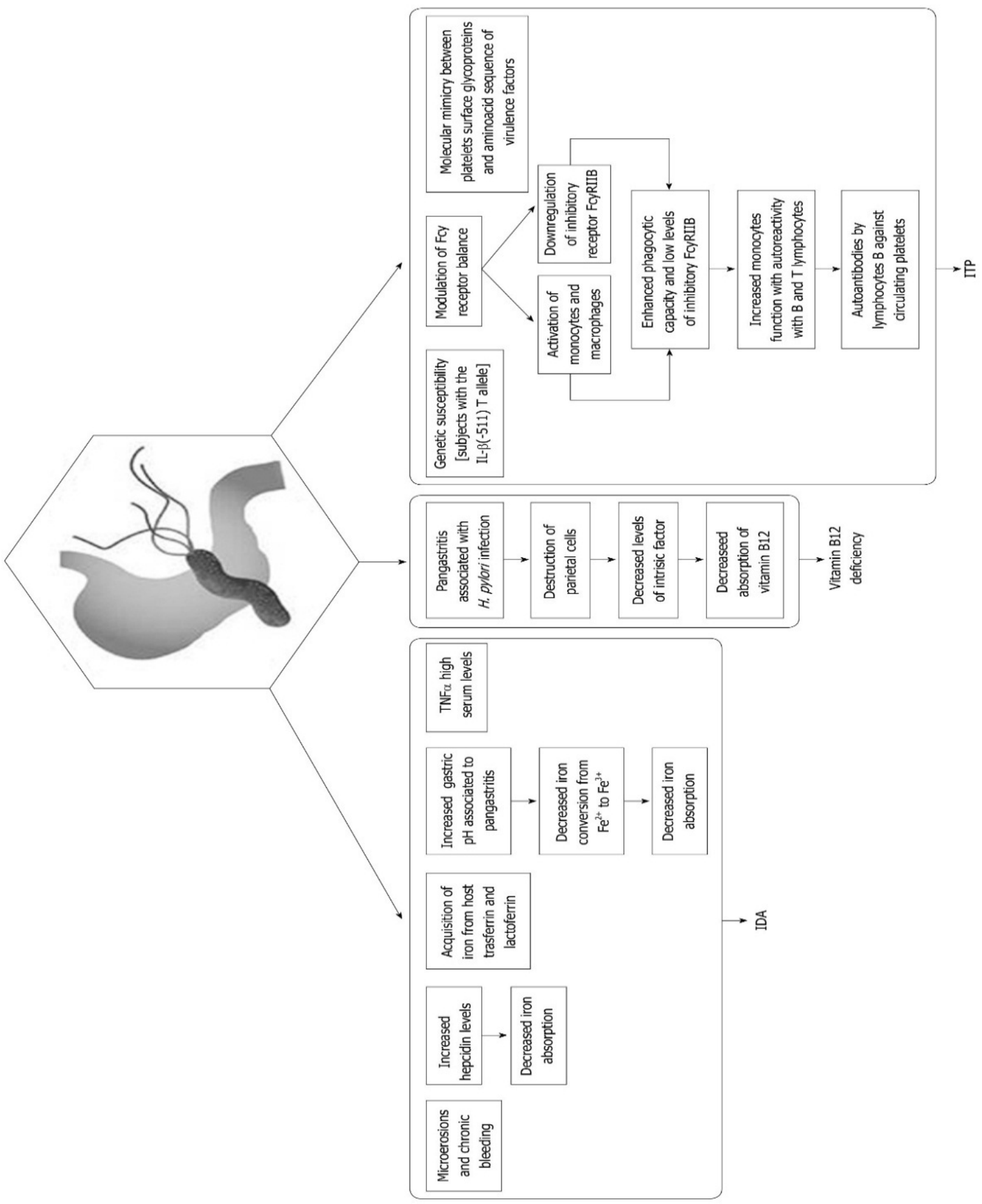

شكل و. مكانيسمهاى احتمالى كه منجر به ارتباط بين بيمارىهاى هماتولوزيك با عفونت H. pylori مىشود ( •م). 
جندين سال كذشته مكانيسم احتمالى H. pylori در ايجاد اين بيمارى ها مورد بررسى قرار كرفته است. سياسگزارى

از تمام عزيزانى كه ما را در تهيه و نوشتن اين مقاله يارى

$$
\text { نموده اند كمال تشكر را داريم. }
$$

$$
\text { تعارض در منافع }
$$

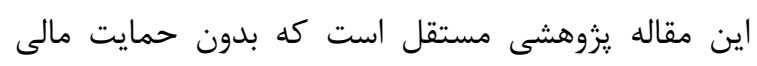

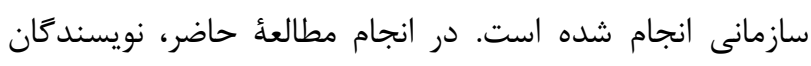

$$
\text { هيج كونه تضاد منافعى نداشتهاند. }
$$

\section{Referance}

1. Park SK. Extra-digestive Manifestations of Helicobacter pylori Infection-An Overview. Extradigestive Manifestations of Helicobacter Pylori Infection: An Overview. 2016:1. [DOI:10.5772/63226]

2. Kato M, Toda A, Yamamoto-Honda R, Arase Y, Sone H. Association between Helicobacter pylori infection, eradication and diabetes mellitus. Journal of diabetes investigation. 2019;10(5):1341-6.

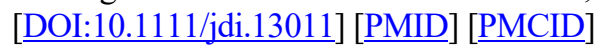

3. Darvishi M, Ziari K, Mohebbi H, Alizadeh K. Association between iron deficiency anemia and Helicobacter pylori infection among children under six years in Iran. Acta Medica Iranica. 2015:220-4.

4. Foroutan M, Loloei B, Irvani S, Azargashb E. Accuracy of rapid urease test in diagnosing Helicobacter pylori infection in patients using NSAIDs. Saudi journal of gastroenterology: official journal of the Saudi Gastroenterology Association. 2010;16(2):110. [DOI:10.4103/1319-3767.61238] [PMID] [PMCID]

5. Mentis A-FA, Boziki M, Grigoriadis N, Papavassiliou AG. Helicobacter pylori infection and gastric cancer biology: tempering a double-edged sword. Cellular and Molecular Life Sciences. 2019;76(13):2477-86. [DOI:10.1007/s00018-019-03044-1] [PMID]

6. Cover TL, Blaser MJ. Helicobacter pylori in health and disease. Gastroenterology. 2009;136(6):1863-73. [DOI:10.1053/j.gastro.2009.01.073] [PMID] [PMCID]

7. Blaser MJ, Atherton JC. Helicobacter pylori persistence: biology and disease. The Journal of clinical investigation. 2004;113(3):321-33. [DOI:10.1172/JCI20925] [피] [PMCID]

8. Diaconu S, Predescu A, Moldoveanu A, Pop C, Fierbinţeanu-Braticevici C. Helicobacter pylori infection: old and new. Journal of medicine and life. 2017;10(2):112.

$$
\begin{aligned}
& \text { نتايج حاصل از مطالعات مختلف در جندين سال كذشته نشان }
\end{aligned}
$$

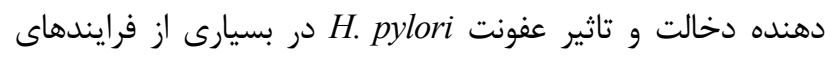

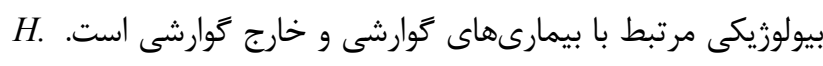

$$
\begin{aligned}
& \text { pylori }
\end{aligned}
$$

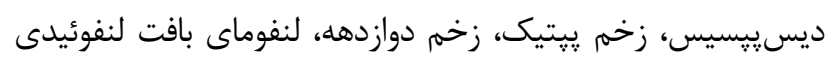

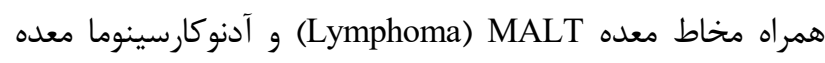

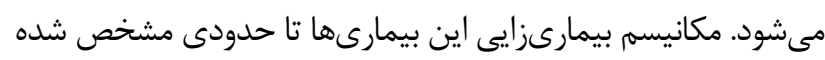

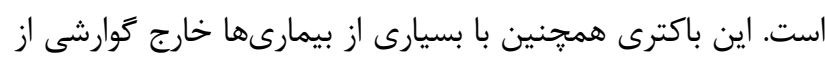

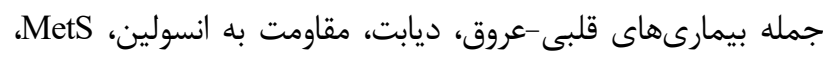

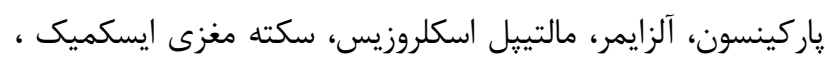

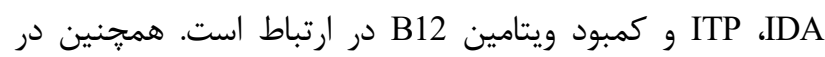

9. Kao C-Y, Sheu B-S, Wu J-J. Helicobacter pylori infection: An overview of bacterial virulence factors and pathogenesis. Biomedical journal. 2016;39(1):14-23. [DOI:10.1016/j.bj.2015.06.002] [MID] [PMCID]

10. Buzás GM. Metabolic consequences of Helicobacter pylori infection and eradication. World journal of gastroenterology: WJG. 2014;20(18):5226. [DOI:10.3748/wjg.v20.i18.5226] [PMID] [MCID]

11. Franceschi F, Gasbarrini A, Polyzos SA, Kountouras J. Extragastric diseases and Helicobacter pylori. Helicobacter. 2015;20:40-6. [DOI:10.1111/hel.12256] [PMID]

12. Correa P, Piazuelo MB. Natural history of Helicobacter pylori infection. Digestive and Liver Disease. 2008;40(7):490-6. [DOI:10.1016/j.dld.2008.02.035]

[PMID] [PMCID]

13. Razavi A, Bagheri N, Azadegan-Dehkordi F, Shirzad M, Rahimian G, Rafieian-Kopaei M, et al. Comparative immune response in children and adults with $\mathrm{H}$. pylori infection. Journal of immunology research. 2015;2015. [DOI:10.1155/2015/315957] [PMID] [PMCID]

14. Crew KD, Neugut AI. Epidemiology of gastric cancer. World journal of gastroenterology: WJG. 2006;12(3):354. [DOI:10.3748/wjg.v12.i3.354] [PMID] [PMCID]

15. O'connor A, O'morain CA, Ford AC. Population screening and treatment of Helicobacter pylori infection. Nature Reviews Gastroenterology \& Hepatology. 2017;14(4):230-40. [DOI:10.1038/nrgastro.2016.195] [PMID]

16. Sato M, Miura K, Kageyama C, Sakae H, Obayashi Y, Kawahara Y, et al. Association of host immunity with Helicobacter pylori infection in recurrent gastric cancer. Infectious agents and cancer. 2019;14(1):4. [DOI:10.1186/s13027-019-0221-1] [PMID] [PMCID] 
17. Suerbaum S, Michetti P. Helicobacter pylori infection. New England Journal of Medicine. 2002;347(15):117586. [DOI:10.1056/NEJMra020542] [PMID]

18. Zullo A, Hassan C, De Francesco V, Repici A, Manta R, Tomao S, et al. Helicobacter pylori and functional dyspepsia: an unsolved issue? World Journal of Gastroenterology: WJG. 2014;20(27):8957.

19. Qian B, Ma S, Shang L, Qian J, Zhang G. Effects of Helicobacter pylori eradication on gastroesophageal reflux disease. Helicobacter. 2011;16(4):255-65. [DOI:10.1111/j.1523-5378.2011.00846.x] [PMID]

20. Xie T, Cui X, Zheng H, Chen D, He L, Jiang B. Metaanalysis: eradication of Helicobacter pylori infection is associated with the development of endoscopic gastroesophageal reflux disease. European Journal of Gastroenterology \& Hepatology. 2013;25(10):1195-205. [DOI:10.1097/MEG.0b013e328363e2c7] [PMID]

21. Sugimoto M, Uotani T, Ichikawa H, Andoh A, Furuta T. Gastroesophageal reflux disease in time covering eradication for all patients infected with Helicobacter pylori in Japan. Digestion. 2016;93(1):24-31. [DOI:10.1159/000441741] [PMID]

22. Manolakis A, Kapsoritakis AN, Potamianos SP. A review of the postulated mechanisms concerning the association of Helicobacter pylori with ischemic heart disease. Helicobacter. 2007;12(4):287-97. [DOI:10.1111/j.15235378.2007.00511.x] [PMID]

23. Wang J-W, Tseng K-L, Hsu C-N, Liang C-M, Tai W-C, $\mathrm{Ku} \mathrm{M}-\mathrm{K}$, et al. Association between Helicobacter pylori eradication and the risk of coronary heart diseases. PLoS One. 2018;13(1):e0190219. [DOI:10.1371/journal.pone.0190219] [PMID] [MCID]

24. Lai C-Y, Yang T-Y, Lin C-L, Kao C-H. Helicobacter pylori infection and the risk of acute coronary syndrome: a nationwide retrospective cohort study. European Journal of Clinical Microbiology \& Infectious Diseases. 2015;34(1):69-74. [DOI:10.1007/s10096-014-2207-7] [PMID]

25. Hughes WS. An Hypothesis: The Dramatic Decline in Heart Attacks in the U nited S tates is Temporally Related to the Decline in Duodenal Ulcer Disease and $\mathrm{H}$ elicobacter pylori Infection. Helicobacter. 2014;19(3):239-41. [DOI:10.1111/hel.12123] [PMID]

26. Eshraghian A, Eshraghian H, Ranjbar OG. Insulin resistance and metabolic syndrome: is Helicobacter pylori criminal? Minerva gastroenterologica e dietologica. 2011;57(4):379.

27. Yang GH, Wu JS, Yang YC, Huang YH, Lu FH, Chang CJ. Gastric H elicobacter pylori infection associated with risk of diabetes mellitus, but not prediabetes. Journal of Gastroenterology and Hepatology. 2014;29(10):1794-9. [DOI:10.1111/jgh.12617] [PMID]
28. Ražuka-Ebela D, Giupponi B, Franceschi F. Helicobacter pylori and extragastric diseases. Helicobacter. 2018;23:e12520. [DOI:10.1111/hel.12520] [PMID]

29. Goni E, Franceschi F. Helicobacter pylori and extragastric diseases. Helicobacter. 2016;21:45-8. [DOI:10.1111/hel.12340] [PMID]

30. He C, Yang Z, Lu N-H. Helicobacter pylori infection and diabetes: is it a myth or fact? World Journal of Gastroenterology: WJG. 2014;20(16):4607. [DOI:10.3748/wjg.v20.i16.4607] [PMID] [PMCID]

31. Plummer M, Franceschi S, Vignat J, Forman D, de Martel C. Global burden of gastric cancer attributable to Helicobacter pylori. International journal of cancer. 2015;136(2):487-90. [DOI:10.1002/ijc.28999] [PMID]

32. Albaker WI. Helicobacter pylori infection and its relationship to metabolic syndrome: Is it a myth or fact? Saudi journal of gastroenterology: official journal of the Saudi Gastroenterology Association. 2011;17(3):165. [DOI:10.4103/1319-3767.80377] [PMID] [PMCID]

33. Lim SH, Kim N, Kwon JW, Kim SE, Baik GH, Lee JY, et al. Positive association between Helicobacter pylori infection and metabolic syndrome in a Korean population: a multicenter nationwide study. Digestive diseases and sciences. 2019;64(8):2219-30. [DOI:10.1007/s10620019-05544-3] [PMID]

34. Nabipour I, Vahdat K, Jafari SM, Pazoki R, Sanjdideh Z. The association of metabolic syndrome and Chlamydia pneumoniae, Helicobacter pylori, cytomegalovirus, and herpes simplex virus type 1: the Persian Gulf Healthy Heart Study. Cardiovascular diabetology. 2006;5(1):25. [DOI:10.1186/1475-2840-5-25] [PMID] [PMCID]

35. Chen TP, Hung HF, Chen MK, Lai HH, Hsu WF, Huang $\mathrm{KC}$, et al. Helicobacter pylori infection is positively associated with metabolic syndrome in Taiwanese adults: a cross-sectional study. Helicobacter. 2015;20(3):184-91. [DOI:10.1111/hel.12190] [PMID]

36. Polyzos SA, Kountouras J, Zavos C, Deretzi G. The association between Helicobacter pylori infection and insulin resistance: a systematic review. Helicobacter. 2011;16(2):79-88. 5378.2011.00822.x] [PMID]

37. Chen Y-Y, Fang W-H, Wang C-C, Kao T-W, Chang Y$\mathrm{W}, \mathrm{Wu} \mathrm{C}-\mathrm{J}$, et al. Helicobacter pylori infection increases risk of incident metabolic syndrome and diabetes: a cohort study. PloS one. 2019;14(2):e0208913. [DOI:10.1371/journal.pone.0208913] [PMID] [PMCID]

38. Cheng D-d, He C, Ai H-h, Huang Y, Lu N-h. The possible role of Helicobacter pylori infection in non-alcoholic fatty liver disease. Frontiers in microbiology. 2017;8:743. [DOI:10.3389/fmicb.2017.00743] [PMID] [PMCID]

39. Banić M, Franceschi F, Babić Z, Gasbarrini A. Extragastric $\mathrm{M}$ anifestations of $\mathrm{H}$ elicobacter pylori $\mathrm{I}$ nfection. Helicobacter. 2012;17:49-55. [DOI:10.1111/j.1523-5378.2012.00983.x] [PMID] 
40. Doulberis M, Kotronis G, Thomann R, Polyzos SA, Boziki M, Gialamprinou D, et al. Impact of Helicobacter pylori on Alzheimer's disease: What do we know so far? Helicobacter. 2018;23(1):e12454. [DOI:10.1111/hel.12454] [PMID]

41. Kountouras J, Deretzi G, Gavalas E, Zavos C, Polyzos SA, Kazakos E, et al. A proposed role of human defensins in Helicobacter pylori-related neurodegenerative disorders. Medical hypotheses. 2014;82(3):368-73. [DOI:10.1016/j.mehy.2013.12.025] [PMID]

42. Roubaud Baudron C, Franceschi F, Salles N, Gasbarrini A. Extragastric Diseases and $\mathrm{H}$ elicobacter pylori. Helicobacter. 2013;18:44-51. [DOI:10.1111/hel.12077] [PMID]

43. Dardiotis E, Tsouris Z, Mentis A-FA, Siokas V, Michalopoulou A, Sokratous M, et al. H. pylori and Parkinson's disease: meta-analyses including clinical severity. Clinical neurology and neurosurgery. 2018;175:16-24. [DOI:10.1016/j.clineuro.2018.09.039] [PMID]

44. Álvarez-Arellano L, Maldonado-Bernal C. Helicobacter pylori and neurological diseases: Married by the laws of inflammation. World journal of gastrointestinal pathophysiology. [DOI:10.4291/wigp.v5.i4.400] [PMID] [PMCID]

45. Tan AH, Mahadeva S, Marras C, Thalha AM, Kiew CK, Yeat $\mathrm{CM}$, et al. Helicobacter pylori infection is associated with worse severity of Parkinson's disease. Parkinsonism \& related disorders. 2015;21(3):221-5. [DOI:10.1016/j.parkreldis.2014.12.009] [PMID]

46. Gavalas E, Kountouras J, Boziki M, Zavos C, Polyzos SA, Vlachaki E, et al. Relationship between Helicobacter pylori infection and multiple sclerosis. Annals of gastroenterology: quarterly publication of the Hellenic Society of Gastroenterology. 2015;28(3):353.

47. Gerges SE, Alosh TK, Khalil SH, El Din MMW. Relevance of Helicobacter pylori infection in Egyptian multiple sclerosis patients. The Egyptian Journal of Neurology, Psychiatry and Neurosurgery. 2018;54(1):41. [DOI:10.1186/s41983-018-0043-x] [PMID] [PMCID]

48. Shindler-Itskovitch T, Chodick G, Shalev V, Muhsen K. Helicobacter pylori infection and prevalence of stroke. Helicobacter. [DOI:10.1111/hel.12553] [PMID]

49. Xu Z, Wang H, Lin Y, Zhai Q, Sun W, Wang Z, et al. The Impacts of Peptic Ulcer on Functional Outcomes of Ischemic Stroke. Journal of Stroke and Cerebrovascular Diseases. 2019;28(2):311-6. [DOI:10.1016/j.jstrokecerebrovasdis.2018.09.056] [PMID]

50. Gravina AG, Zagari RM, De Musis C, Romano L, Loguercio C, Romano M. Helicobacter pylori and extragastric diseases: a review. World journal of gastroenterology.

2018;24(29):3204. [DOI:10.3748/wjg.v24.i29.3204] [PMID] [PMCID]

51. Tsay F-W, Hsu P-I. H. pylori infection and extragastroduodenal diseases. Journal of biomedical science. 2018;25(1):65.

[DOI:10.1186/s12929-018-0469-6] [PMID] [PMCID]

52. Wong F, Rayner-Hartley E, Byrne MF. Extraintestinal manifestations of Helicobacter pylori: a concise review. World journal of gastroenterology: WJG. 2014;20(34):11950. [DOI:10.3748/wjg.v20.i34.11950] [PMID] [PMCID]

53. Campuzano-Maya G. Hematologic manifestations of Helicobacter pylori infection. World journal of gastroenterology: WJG. 2014;20(36):12818. [DOI:10.3748/wjg.v20.i36.12818] [PMID] [PMCID]

54. Qu X-H, Huang X-L, Xiong P, Zhu C-Y, Huang Y-L, Lu L-G, et al. Does Helicobacter pylori infection play a role in iron deficiency anemia? A meta-analysis. World journal of gastroenterology: WJG. 2010;16(7):886.

55. Hou B, Zhang M, Liu M, Dai W, Lin Y, Li Y, et al. Association of active Helicobacter pylori infection and anemia in elderly males. BMC infectious diseases. 2019;19(1):228. [DOI:10.1186/s12879-019-3849-y] [PMID] [PMCID]

56. Jackson SC, Beck P, Buret AG, O'Connor PM, Meddings $\mathrm{J}$, Pineo $\mathrm{G}$, et al. Long term platelet responses to Helicobacter pylori eradication in Canadian patients with immune thrombocytopenic purpura. International journal of hematology. 2008;88(2):212-8. [DOI:10.1007/s12185008-0138-8] [PMID]

57. Bai Y, Wang Z, Bai X, Yu Z, Cao L, Zhang W, et al. Cross-reaction of antibody against Helicobacter pylori urease B with platelet glycoprotein IIIa and its significance in the pathogenesis of immune thrombocytopenic purpura. International journal of hematology. 2009;89(2):142-9. [DOI:10.1007/s12185008-0247-4] [PMID]

58. Ravi K, Joseph J, Thomas DM. Helicobacter pylori infection and vitamin B-12 deficiency-A cross sectional study. Asian Journal of Medical Sciences. 2017;8(4):1620. [DOI:10.3126/ajms.v8i4.17280]

59. Lahner E, Persechino S, Annibale B. Micronutrients (Other than iron) and Helicobacter pylori infection: a systematic review. Helicobacter. 2012;17(1):1-15. [DOI:10.1111/j.1523-5378.2011.00892.x] [PMID]

60. Kadhim G, Shikh M, Omar H, Ismail A. Vitamin B12 deficiency in Helicobacter pylori infected patients. Open Access Library Journal. 2018;5(3):1-4. [DOI:10.4236/oalib.1104172] 